\title{
A Model for Active-site Formation Process in DMSO Reductase Family Molybdenum Enzymes Involving Oxido-alcoholato- and Oxido-thiolato-molybdenum(VI) Core Structures
}

\author{
Hideki Sugimoto*, ${ }^{\star}$, Masanori Sato $^{\dagger}$, Kaori Asano", Takeyuki Suzukiđ, Kaoru Mieda ${ }^{\ddagger}$,

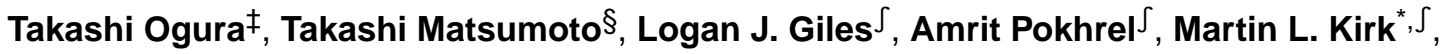 \\ and Shinobu Itoh ${ }^{*}, \dagger$ \\ †Department of Material and Life Science, Division of Advanced Science and Biotechnology, \\ Graduate School of Engineering, Osaka University, 2-1 Yamadaoka, Suita, Osaka 565-0871, \\ Japan \\ "Comprehensive Analysis Center, The Institute of Scientific and Industrial Research (ISIR), \\ Osaka University, 8-1 Mihogaoka, Ibaraki, Osaka 567-0057, Japan \\ ‡Picobiology Institute, Graduate School of Life Science, University of Hyogo, RSC-UH Leading \\ Program Center, 1-1-1 Koto, Sayo-cho, Sayo-gun, Hyogo 678-0057, Japan \\ §Rigaku Corporation, Akishima, Tokyo, 196-8666, Japan \\ ${ }^{5}$ Department of Chemistry and Chemical Biology, The University of New Mexico, MSC03 2060, 1 \\ University of New Mexico, Albuquerque, NM 87131-0001, USA
}

\section{Abstract}

\begin{abstract}
New bis(ene-1,2-dithiolato)-oxido-alcoholato-molybdenum(VI) and -oxido-thiolatomolybdenum(VI) anionic complexes, denoted as $\left[\mathbf{M o}^{\mathbf{V I}} \mathbf{O}(\boldsymbol{E R}) \mathbf{L}_{2}\right]^{-}(E=\mathrm{O}, \mathrm{S} ; \mathrm{L}=$ dimethoxycarboxylate-1,2-ethylenedithiolate), have been obtained from the reaction of the corresponding dioxido-moybdenum(VI) precursor complex with either an alcohol or a thiol in the presence of an organic acid (e.g. 10-camphorsulfonic acid) at low temperature. The $\left[\mathbf{M o}^{\mathrm{VI}} \mathbf{O}(\boldsymbol{E R}) \mathbf{L}_{2}\right]^{-}$complexes have been isolated and characterized, and the structure of $\left[\mathbf{M o}^{\mathrm{VI}} \mathbf{O}(\boldsymbol{O R}) \mathbf{L}_{2}\right]^{-}$has been determined by X-ray crystallography. The Mo(VI) center in $\left.{ }^{[M o}{ }^{\mathrm{VI}} \mathbf{O}(\boldsymbol{O R}) \mathbf{L}_{2}\right]^{-}$exhibits a distorted octahedral geometry with the two ene-1,2-dithiolate ligands being symmetry inequivalent. The computed structure of $\left[\mathbf{M o}^{\mathbf{V I}} \mathbf{O}(\mathbf{S R}) \mathbf{L}_{2}\right]^{-}$is essentially identical to that of $\left[\mathbf{M o}^{\mathbf{V I}} \mathbf{O}(\mathbf{O R}) \mathbf{L}_{2}\right]^{-}$. The electronic structures of the resulting molybdenum(VI) complexes have been evaluated using electronic absorption spectroscopy and bonding calculations. The nature of the distorted $\mathrm{O}_{\mathrm{h}}$ geometry in these $\left[\mathbf{M o}^{\mathbf{V I}} \mathbf{O}(\boldsymbol{E E t}) \mathbf{L}_{2}\right]^{-}$complexes results in a LUMO wavefunction that possesses strong $\pi^{*}$ interactions between the $\operatorname{Mo}\left(\mathrm{d}_{\mathrm{xy}}\right)$ orbital and the $\operatorname{cis} \mathrm{S}\left(\mathrm{p}_{\mathrm{z}}\right)$ orbital localized on one sulfur donor from a single ene-1,2-dithiolate ligand. The presence of covalent Mo- $\mathrm{S}_{\text {dithiolene }}$ bonding interaction in these monooxido $\mathrm{Mo}(\mathrm{VI})$ compounds contributes to
\end{abstract}

\footnotetext{
* sugimoto@mls.eng.osaka-u.ac.jp (HS), mkirk@unm.edu (MLK), shinobu@mls.eng.osaka-u.ac.jp (SI).

Supporting Information

Experimental details, Figures S1-S8 and Tables S1-S2. Additional computational data, including coordinates and energies for all described stationary structures. This material is available free of charge via the Internet at http://pubs.acs.org.
} 
their low energy LMCT transitions. A second important $\mathrm{d}-\mathrm{p} \pi$ bonding interaction derives from the $\sim 180^{\circ} \mathrm{O}_{\text {oxo- }}$-Mo- $E-\mathrm{C}$ dihedral angle involving the alcoholate and thiolate donors, and this contributes to ancillary ligand contributions to the electronic structure of these species. The formation of $\left[\mathbf{M o}^{\mathbf{V I}} \mathbf{O}(\boldsymbol{O E t}) \mathbf{L}_{2}\right]^{-}$and $\left[\mathbf{M o}^{\mathbf{V I}} \mathbf{O}(S \mathbf{E t}) \mathbf{L}_{2}\right]^{-}$from the dioxidomolybdenum(VI) precursor may be regarded as a model for the active-site formation process that occurs in the DMSO reductase family of pyranopterin molybdenum enzymes.

\section{Graphical Abstract}

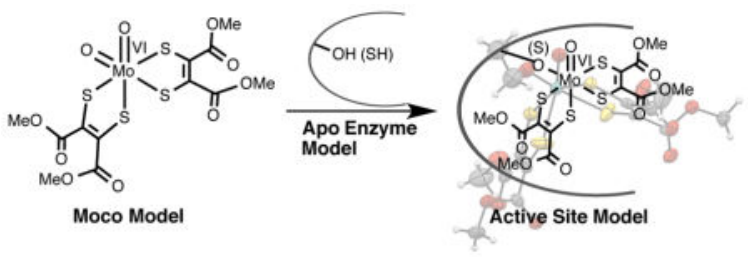

Bis(ene-1,2-dithiolato)-oxido-alcoholato-molybdenum(VI) and -oxido-thiolato-molybdenum(VI) complexes are prepared by the reaction of the dioxido-moybdenum(VI) complex and either alcohols or hexanethiol in the presence of 10-camphorsulfonic acid. The complexes exhibit significant $\pi$-delocalization between the molybdenum(VI) atom and one of the ene-1,2-dithiolate ligands. The $\mathrm{Mo}\left(\mathrm{d}_{\mathrm{xy}}\right)$ and cis $\mathrm{S}\left(\mathrm{p}_{\mathrm{z}}\right)$ interactions are responsible for the lower energy charge transfer bands. The LUMO has little contribution of the alcoholate ligand whereas the thiolate ligand significantly contributes to the orbital.

\section{INTRODUCTION}

Pyranopterin molybdenum (Mo) enzymes are found in nearly all organisms and catalyze a wide variety of important chemical transformations that are involved in global carbon, nitrogen, and sulfur biogeochemical cycles. ${ }^{1-4}$ The most abundant form of Mo in Nature is the biologically active molybdate ion, $\mathrm{MoO}_{4}{ }^{2-}$. Molybdate enters the cell via active transport processes where it can be coordinated by the ene-1,2-dithiolate of molybdopterin (MPT). For enzymes of the dimethyl sulfoxide reductase (DMSOR) family, molybdate is converted to a mono-Mo-MPT form and, then, to a bis-Mo-MPT form, also referred to as $\operatorname{Moco}\left(\mathrm{MoO}_{\mathrm{n}}(\mathrm{MPT})_{2}(\mathrm{n}=1\right.$ or 2$\left.)\right)$, by a MobA protein. ${ }^{5-8}$ Here, the Mo ion is ligated by the dithiolene chelates of two separate MPTs (Figure 1) and one or two terminal oxide ligands. ${ }^{5-8}$ Although the biosynthesis of MPT has been elegantly investigated, ${ }^{1-8}$ the insertion of Moco into DMSOR family apo-enzymes is still the subject of active investigation. ${ }^{9,10}$ It is known that specific Moco binding chaperones are required for insertion of Moco into apoenzymes of the DMSOR family in order to form catalytically competent holoenzymes. A sixth ligand is typically found to bind to the Mo ion in active enzyme forms, which may be a serine (-OH), cysteine (-SH), selenocysteine (-SeH), aspartate $(-\mathrm{COOH})$, or hydroxide. ${ }^{11-14}$ Open questions remain regarding the nature of the core structure of the transferred Moco and how the sixth ligand is incorporated into the active site, although it is hypothesized that either a dioxidomolybdenum(VI) $\left(\mathrm{Mo}^{\mathrm{VI}} \mathrm{O}_{2}, \mathrm{n}=\right.$ 2) or a monooxidomolybdenum(IV) $\left(\mathrm{Mo}^{\mathrm{IV}} \mathrm{O}, \mathrm{n}=1\right)$ form (Figure 1, left) of bis-Mo-MPT represents the structure of the cofactor prior to coordination of the sixth ligand. ${ }^{9,10} \mathrm{Mo}^{\mathrm{VI}} \mathrm{O}_{2}$ 
$(\mathrm{n}=2)$ form will give a $\mathrm{Mo}^{\mathrm{VI}} \mathrm{O}(E \mathrm{R})(E=\mathrm{O}, \mathrm{S}$, or Se $)$ active site upon a reaction with $-\mathrm{EH}$ of an apo enzyme whereas $\mathrm{Mo}^{\mathrm{IV}} \mathrm{O}(\mathrm{n}=1)$ form will give a $\mathrm{Mo}^{\mathrm{IV}}(E R)$ active site by a reaction with -EH of an apo enzyme. Furthermore, full characterization of the resulting holo-enzyme active sites, particularly when in the Mo(VI) oxidation state, remains difficult due to the instability resulting from potential overoxidation of the MPT, thiolate, and/or selenate ligands as well as hydrolytic reactions at the Mo(VI) center. ${ }^{1-3}$ Thus, it is of fundamental importance to understand whether a Mo-ER $(\mathrm{E}=\mathrm{O}, \mathrm{S}$, or Se) bond can be formed by the reaction of a $\mathrm{Mo}^{\mathrm{VI}} \mathrm{O}_{2}$ or $\mathrm{Mo}^{\mathrm{IV}} \mathrm{O}$ center with either an alcohol, thiol, or selenol. In this manuscript, we use small molecule analogs to interrogate this reaction chemistry and probe electronic structure differences as a function of -SR and -OR ancillary ligation in well-defined model systems.

In modeling studies of pyranopterin molybdenum enzyme active sites, there have been no attempts reproduce the proposed formation step of the catalytically competent molybdenum sites found in DMSOR family enzymes. ${ }^{15-19}$ Although some excellent model compounds have been synthesized that mimic reduced DMSOR active sites, including des-oxido bis(ene-1,2-dithiolato)( $E \mathrm{R})$ molybdenum(IV) complexes $(E=\mathrm{O}, \mathrm{S}, \mathrm{Se} ; \mathrm{R}=$ alkyl), their preparation methods are different from that proposed for the formation of the enzyme active sites (Figure 1). ${ }^{20-24}$ In this study, we have generated monooxido $\mathrm{Mo}^{\mathrm{VI}} \mathrm{O}(\mathrm{OR} / \mathrm{SR}$ ) complexes by the reaction of a dioxido $\mathrm{Mo}^{\mathrm{VI}} \mathrm{O}_{2}$ complex with an alcohol or a thiol, which can be regarded as a model reaction for active site formation in DMSOR family enzymes. Here, both $\mathrm{Mo}^{\mathrm{VI}} \mathrm{O}_{2}$ and $\mathrm{Mo}^{\mathrm{IV}} \mathrm{O}$ complexes $\left(\mathbf{M o}^{\mathrm{VI}} \mathbf{O}_{2} \mathbf{L}_{\mathbf{2}}\right.$ and $\left.\mathbf{M o}^{\mathrm{IV}} \mathbf{O L}_{2}\right)$ of dimethoxycarboxylate-1,2-ethylenedithiolate (L) were employed as the Moco models (see, Chart 1). ${ }^{25,26}$

\section{EXPERIMENTAL SECTION}

\section{General}

All reagents and solvents were used as received unless otherwise noted. All reactions were carried out under a dinitrogen or an argon atmosphere using standard Schlenk techniques or a Miwa D80-1KP glovebox. Propionitrile was dried with $\mathrm{CaH}_{2}$ and then $\mathrm{P}_{2} \mathrm{O}_{5}$ and distilled under dinitrogen atmosphere prior to use. $\left(\mathrm{Et}_{4} \mathrm{~N}\right)_{2}\left[\mathrm{Mo}^{\mathrm{VI}} \mathrm{O}_{2} \mathrm{~L}_{2}\right]\left(\left[\mathbf{M o}^{\mathbf{V I}} \mathbf{O}_{2} \mathbf{L}_{2}\right]^{2-}\right)$ was prepared by following the established literature procedure. ${ }^{26}$

\section{Synthesis and Characterization of Complexes}

$\left(\mathrm{Ph}_{4} \mathbf{P}\right)\left[\mathrm{Mo}^{\mathrm{VI}} \mathrm{O}(\mathrm{OEt}) \mathrm{L}_{2}\right.$ ]-Under an $\mathrm{Ar}$ atmosphere, $4 \mathrm{~mL}$ of ethanol was added to a $1 \mathrm{~mL}$ acetonitrile solution of $\left(\mathrm{Et}_{4} \mathrm{~N}\right)_{2}\left[\mathrm{Mo}^{\mathrm{VI}} \mathrm{O}_{2} \mathrm{~L}_{2}\right](60.7 \mathrm{mg}, 75.8 \mu \mathrm{mol})$. This mixture was cooled to $-40{ }^{\circ} \mathrm{C}$, and an acetonitrile solution of 10-camphorsulfonic acid ( $207 \mathrm{mM}, 380 \mu \mathrm{L}, 78.7$ $\mu \mathrm{mol})$ was added. The color of the brown solution then changed to purple. To the purple solution, $2 \mathrm{~mL}$ of an ethanol solution of $\mathrm{Ph}_{4} \mathrm{PBr}(125.3 \mathrm{mg}, 298.7 \mu \mathrm{mol})$ was added, and the solution was concentrated to ca. $500 \mu \mathrm{L}$ to yield a deep-purple solid. The solid was collected by filtration and washed with ethanol and ether to yield a deep-purple solid product. Yield $48.5 \mathrm{mg}, 53.4 \mu \mathrm{mol}$ (70\%). Anal. Calcd. for $\mathrm{C}_{38} \mathrm{H}_{37} \mathrm{MoO}_{10} \mathrm{PS}_{4}$ (MW = 908.88): C 50.22; $\mathrm{H}$ 4.10; N 0.00. Found: $\mathrm{C} 50.36 ; \mathrm{H} 4.28 ; \mathrm{N} 0.00 \% .{ }^{1} \mathrm{H}$ NMR $\left(\mathrm{CD}_{3} \mathrm{CN}\right.$, anionic part): $\delta 4.10$ (q, $J=6.8 \mathrm{~Hz}, 2 \mathrm{H}), 3.72(\mathrm{~s}, 12 \mathrm{H}), 1.33(\mathrm{t}, J=6.8 \mathrm{~Hz}, 3 \mathrm{H}) . \mathrm{UV}$-vis (acetonitrile): $\lambda_{\max }=539 \mathrm{~nm}$ 
$\left(\varepsilon=2380 \mathrm{M}^{-1} \mathrm{~cm}^{-1}\right), 742$ (1470). CSI-MS $\left(\mathrm{CH}_{3} \mathrm{CN}\right): 570.9$ [M] $]^{-}$. IR (KBr): 890

$\mathrm{cm}^{-1}(\mathrm{Mo}=\mathrm{O}) . \mathrm{CV}\left(0.1 \mathrm{~V} \mathrm{~s}^{-1}, \mathrm{CH}_{3} \mathrm{CN}\right): E_{1 / 2}$ (quasi-rev. $)=-0.52 \mathrm{~V}$ vs. SCE.

Generation of [Mo $\left.{ }^{\mathrm{Vl}} \mathrm{O}\left(\mathrm{SC}_{6} \mathrm{H}_{13}\right) \mathrm{L}_{\mathbf{2}}\right]^{-}$Complex-A typical procedure is follows: $25 \mu \mathrm{L}$ of a propionitrile solution of 10-Camphorsulfonic acid $(20.0 \mathrm{mM})$ was added to $5 \mathrm{~mL}$ of a propionitrile solution containing $\left[\mathrm{Mo}^{\mathrm{VI}} \mathrm{O}_{2} \mathrm{~L}_{2}\right]^{2-}(1.0 \mathrm{mM})$ and 1-hexanethiol $(100.0 \mathrm{mM})$ at $-80{ }^{\circ} \mathrm{C}$ through a septum cap of the quartz cell using a gastight syringe.

Electronic Structure Calculations-Gas-phase geometry optimizations, electronic structure, and spectroscopic calculations for $\left[\mathbf{M o}^{\mathbf{V I}} \mathbf{O}(\boldsymbol{E} \mathbf{E t}) \mathbf{L}_{\mathbf{2}}\right]^{-}(E=\mathrm{O}$ or $\mathrm{S})$ were performed at the density functional level of theory (DFT) using the Gaussian 09 revision C. 01 software package. ${ }^{27}$ The calculations utilized the $\mathrm{PBE}^{28,29}$ exchange-correlation functional with the def2-tzvp basis set ${ }^{30}$ for all atoms and an effective core potential on Mo. ${ }^{31}$ The def2-tzvp basis set and effective core potential were obtained from the EMSL basis set exchange website. ${ }^{32,33}$ Orbital compositions were obtained using the Mulliken population analysis method as implemented in Gaussian 09. ${ }^{34}$ Orbital compositions were analyzed utilizing AOMix Revision 6.51. ${ }^{35,36}$ Electronic transitions were computed using time dependent DFT (TD-DFT) methods as implemented in Gaussian 09. ${ }^{37-43}$ The Cartesian coordinates of $\left[\mathbf{M o}^{\mathbf{V I}} \mathbf{O}(\boldsymbol{O E t} / \mathbf{S E t}) \mathbf{L}_{2}\right]^{-}$are listed in Tables $\mathrm{S} 1$ and $\mathrm{S} 2$.

Physical Measurements-FT-IR spectra were recorded using a Jasco FT-IR 4100 spectrometer. Resonance Raman data were collected using a He-Cd laser (Kimmon Koha, IK5651R-G) with an excitation wavelength of $441.6 \mathrm{~nm}$. The scattered radiation was dispersed by a $1 \mathrm{~m}$ single grating spectrograph (Ritsu Oyo Kogaku, MS-100DG) and the Raman scattered light was detected using a liquid nitrogen cooled CCD detector (Horiba Jobin Yvon, Symphony CCD-1024 256-OPEN-1LS). The resonance Raman measurements were collected with the sample in a spinning NMR tube cooled to $-40{ }^{\circ} \mathrm{C}$ using flash cooled dinitrogen gas. ${ }^{1} \mathrm{H}$ NMR spectra were recorded on a JEOL Lambda 300 NMR spectrometer and the TMS signal was adjusted to $0 \mathrm{ppm}$. UV-vis spectra were recorded on an HP-8453 spectrophotometer equipped with a Unisoku thermostat cell holder (USP-203). CSI-MS (cryrospray ionization mass spectra) data were collected using a BRUKER cryospray micrOTOFII.

Electrochemistry-Cyclic voltammetric measurements were performed under a dinitrogen atmosphere using a Hokuto Denko HZ-3000 potentiostat. The electrode set employed in these experiments consisted of a glassy-carbon working electrode (circular, 3 mm diameter), a SCE reference electrode and a platinum counter electrode.

X-ray Crystallography-A single crystal of $\left(\mathrm{PPh}_{4}\right)\left[\mathrm{Mo}^{\mathrm{VI}} \mathrm{O}(O \mathrm{Et}) \mathrm{L}_{2}\right] \cdot$ acetone was deeppurple and was obtained by vapor diffusion of diethyl ether into an acetone solution of the $\left(\mathrm{Et}_{4} \mathrm{~N}\right)\left[\mathrm{Mo}^{\mathrm{VI}} \mathrm{O}(O \mathrm{Et}) \mathrm{L}_{2}\right]$ in the presence of slight excess of $\mathrm{PPh}_{4} \mathrm{Br}$ at $-40{ }^{\circ} \mathrm{C}$. A single crystal of $\left(\mathrm{PPh}_{4}\right)\left[\mathrm{Mo}{ }^{\mathrm{VI}} \mathrm{O}(O \mathrm{Et}) \mathrm{L}_{2}\right] \cdot$ acetone was mounted on a loop, and all measurements were made on a Rigaku XtaLAB P200 diffractometer using multi-layer mirror monochromated $\mathrm{Cu}-\mathrm{Ka}$ radiation at $-180^{\circ} \mathrm{C}$. The structures were solved by direct methods (SIR2011) and refined anisotropically by full-matrix least squares on $F^{2.44}$ The OEt ligand (O2C13C14 atoms) was disordered with respect to the orientation of the O1 (oxide)-Mo1- 
$\mathrm{O} 2-\mathrm{C} 13$ dihedral angles. The disorder was solved with occupancies of 0.86 (main) and 0.14 (minor). The data of the main structure was employed for discussion. The hydrogen atoms were attached at idealized positions on carbon atoms and were not refined. All structures in the final stages of refinement showed no movement in the atom positions. The calculations were performed using the Single-Crystal Structure Analysis Software, version 3.8. ${ }^{45}$ Crystallographic parameters are summarized in Table 1.

\section{RESULTS AND DISCUSSION}

\section{Formation and Characterization of Oxido-alcoholato- and Oxido-thiolato-molybdenum(VI) Complexes}

The $\left[\mathbf{M o}^{\mathrm{VI}} \mathbf{O}_{2} \mathbf{L}_{2}\right]^{2-}$ complex is stable in an acetonitrile solution even in the presence of an excess amount of ethanol (EtOH). However, addition of a strong organic acid such as 10camphorsulfonic acid (CSA) to a propionitrile solution of $\left[\mathbf{M o}^{\mathbf{V I}} \mathbf{O}_{2} \mathbf{L}_{2}\right]^{2-}(0.1 \mathrm{mM})$ containing $0.5 \%$ ethanol $(0.86 \mathrm{mM})$ at $-60{ }^{\circ} \mathrm{C}$ resulted in a color change from orange to purple. ${ }^{46}$ The course of this reaction was followed by UV-vis spectroscopy, and the data that are presented in Figure 2a. The absorption bands at 360 and $423 \mathrm{~nm}$ due to $\left[\mathbf{M o}^{\mathbf{V I}} \mathbf{O}_{2} \mathbf{L}_{\mathbf{2}}\right]^{{ }^{2-}}$ decrease in intensity with the concomitant appearance of the new absorption bands at 539 and $742 \mathrm{~nm}$ with a clear isosbestic point at $473 \mathrm{~nm}$. The final spectrum exhibits absorption bands at $\lambda_{\max }=539 \mathrm{~nm}\left(\varepsilon=2430 \mathrm{M}^{-1} \mathrm{~cm}^{-1}\right)$ and $742 \mathrm{~nm}$ (2130), which are close to those observed for the oxido-siloxido-molybdenum(VI) complex, $\left[\mathbf{M o}^{\mathbf{V I}} \mathbf{O}\left(\mathbf{O S i}^{\mathbf{i}} \mathbf{P r}_{\mathbf{3}}\right) \mathbf{L}_{\mathbf{2}}\right]^{-}\left(\lambda_{\max }=\right.$ $563 \mathrm{~nm}\left(\varepsilon=4301 \mathrm{M}^{-1} \mathrm{~cm}^{-1}\right)$ and 729 (1280) in acetonitrile), ${ }^{47,48}$ suggesting the formation of the expected product $\left[\mathbf{M o}^{\mathbf{V I}} \mathbf{O}(\boldsymbol{O E t}) \mathbf{L}_{2}\right]^{-}$. The titration curves based on absorbance changes at 360,539, and $742 \mathrm{~nm}$ are shown in the inset of Figure 2a, which clearly indicate the $1: 1$ stoichiometry of $\left[\mathbf{M o}^{\mathbf{V}} \mathbf{O}_{2} \mathbf{L}_{2}\right]^{2-}:$ CSA. The CSI-mass spectrum of a propionitrileethanol (200: 1) solution of [ $\left.\mathbf{M o}^{\mathbf{V I}} \mathbf{O}_{\mathbf{2}} \mathbf{L}_{\mathbf{2}}\right]^{2-}$ in the presence of one equiv of CSA taken at $-60{ }^{\circ} \mathrm{C}$ exhibited a peak cluster at $\mathrm{m} / z=570.9$ (Figure $2 \mathrm{~b}$ ). The isotope distribution pattern is consistent with the molecular formula of the oxido-ethanolato-molybdenum(VI) complex, $\left[\mathbf{M o}^{\mathbf{V I}} \mathbf{O}(\boldsymbol{O E t}) \mathbf{L}_{2}\right]^{-}$(Figure S1). On the basis of electronic absorption and CSI mass spectrometry data, we conclude that an oxido-ethanolato-molybdenum(VI) complex supported by two dithiolene ligands (L), [Mo $\left.{ }^{\mathbf{V I}} \mathbf{O}(\boldsymbol{O E t}) \mathbf{L}_{2}\right]^{-}$, has been generated from $\left[\mathbf{M o}^{\mathrm{VI}} \mathbf{O}_{2} \mathbf{L}_{2}\right]^{2-}$ by the reaction with ethanol in the presence of CSA at low temperature. This represents the first example of a bis(ene-1,2-dithiolato)oxido-alcoholato-molybdenum(VI) complex. Given the observed stoichiometry, the formation mechanism of $\left[\mathbf{M o}^{\mathrm{VI}} \mathbf{O}(\boldsymbol{O} \mathbf{E t}) \mathbf{L}_{2}\right]^{-}$ from $\left[\mathbf{M o}^{\mathrm{VI}} \mathbf{O}_{2} \mathbf{L}_{2}\right]^{2-}$ can be hypothesized as shown in Scheme 1. Protonation of one of the two oxide ligands in $\left[\mathbf{M o}^{\mathrm{VI}} \mathbf{O}_{2} \mathbf{L}_{2}\right]^{2-}$ yields an oxido-hydroxido-molybdenum(VI) center as an intermediate, from which a ligand exchange reaction takes place between $\mathrm{OH}^{-}$and $\mathrm{EtO}^{-}$ to yield the observed $\left[\mathbf{M o}^{\mathbf{V I}} \mathbf{O}(\boldsymbol{O E t}) \mathbf{L}_{2}\right]^{-}$product. Since the UV-vis and CSI-mass spectra indicate that $\left[\mathbf{M o}^{{ }^{V I}} \mathbf{O}_{2} \mathbf{L}_{2}\right]^{2-}$ remained intact in the absence of ethanol, the equilibrium between $\left[\mathbf{M o}^{\mathbf{V I}} \mathbf{O}_{2} \mathbf{L}_{2}\right]^{2-}$ and $\left[\mathbf{M o}^{\mathbf{V I}} \mathbf{O}(\mathbf{O H}) \mathbf{L}_{2}\right]^{-}$must lie far to the left, consistent with the general propensity for bis-dithiolene ligated $\mathrm{Mo}(\mathrm{VI})$ species to exist in a dioxidomolybdenum coordination environment. ${ }^{26,49-51}$

The $\mathrm{PPh}_{4}{ }^{+}$salt of $\left[\mathbf{M o}^{\mathrm{VI}} \mathbf{O}(\boldsymbol{O E t}) \mathbf{L}_{2}\right]^{-}$was isolated as a black microcrystalline powder at $-40{ }^{\circ} \mathrm{C}$ by a cation exchange with $\mathrm{PPh}_{4} \mathrm{Br}$. The ${ }^{1} \mathrm{H}$ NMR spectrum and the elemental 
analysis data are consistent with the expected molecular formula (see Experimental details). The $\mathrm{Mo}^{\mathrm{VI}} \equiv \mathrm{O}$ stretch appeared at higher wavenumbers in the IR $(\mathrm{KBr})$ spectrum when compared with those observed for the silylalcoholate derivative $\left(868 \mathrm{~cm}^{-1},\left(\mathrm{Et}_{4} \mathrm{~N}\right)\right.$ $\left.\left[\mathrm{Mo}^{\mathrm{VI}} \mathrm{O}\left(\mathrm{OSi}^{\mathrm{i}} \mathrm{Pr}_{3}\right) \mathrm{L}_{2}\right]\right)$ and $\left(\mathrm{Et}_{4} \mathrm{~N}\right)\left[\mathrm{Mo}^{\mathrm{VI}} \mathrm{O}\left(\mathrm{OSi}^{\mathrm{t}} \mathrm{BuPh}_{2}\right)(\mathrm{bdt})_{2}\right]\left(877 \mathrm{~cm}^{-1}\right.$, bdt $=1,2-$ benzenedithiolate) and was observed at $890 \mathrm{~cm}^{-1}$ (Figure S2 (a)). ${ }^{52} \mathrm{The} \mathrm{Mo}^{\mathrm{VI}} \equiv \mathrm{O}$ stretch was observed in the $\mathrm{CH}_{3} \mathrm{CN}$ solution resonance Raman spectrum of $\left[\mathbf{M o}{ }^{\mathbf{V I}} \mathbf{O}(\boldsymbol{O E t}) \mathbf{L}_{2}\right]^{-}$at $870 \mathrm{~cm}^{-1}$ (Figure S2 (b)). [Mo $\left.{ }^{\mathbf{V I}} \mathbf{O}(\boldsymbol{O E t}) \mathbf{L}_{2}\right]^{-}$displayed one quasi-reversible redox wave at $-0.53 \mathrm{~V}$ vs. SCE in $\mathrm{CH}_{3} \mathrm{CN}$, which is assignable to the $\mathrm{Mo}(\mathrm{VI}) / \mathrm{Mo}(\mathrm{V})$ redox couple. Bulk electrolysis at $-0.65 \mathrm{~V}$ was used to reduce $\left[\mathbf{M o}^{\mathbf{V I}} \mathbf{O}(\boldsymbol{O E t}) \mathbf{L}_{2}\right]^{-}$to the corresponding $\left[\mathrm{Mo}^{\mathrm{V}} \mathrm{O}(\mathrm{OEt}) \mathrm{L}_{2}\right]^{2-}$, but this resulted in the formation of the $\mathrm{Mo}^{\mathrm{V}} \mathrm{OL}_{2}$ complex with dissociation of the $\mathrm{OEt}^{-}$ligand from the electrochemically generated molybdenum(V) center. Attempts to generate $\left[\mathrm{Mo}^{\mathrm{IV}}(\mathrm{OEt}) \mathrm{L}_{2}\right]^{-}$from the monooxido $\mathrm{Mo}(\mathrm{IV})$ complex, $\left[\mathbf{M o}^{\mathbf{I V}} \mathbf{O L}_{2}\right]^{2-}$, and ethanol in a manner similar to that employed for $\left[\mathbf{M o}^{\mathrm{VI}} \mathbf{O}(\boldsymbol{O E t}) \mathbf{L}_{2}\right]^{-}$ were unsuccessful, and the molybdenum(IV) complex remained unchanged. These observations allow us to hypothesize that the bis-Mo-MPT transferred to apo DMSOR family enzymes may possess a bis(MPT)dioxidomolybdenum(VI) structure similar to that observed in [Mo $\left.\mathbf{M o}^{\mathrm{V}} \mathbf{O}_{2} \mathbf{L}_{2}\right]^{2-}$, with one of the two oxide donors being subject to protonation. This would yield a $\left[\mathbf{M o}^{\mathbf{V I}} \mathbf{O}(\mathbf{O H}) \mathbf{L}_{2}\right]^{-}$species with a more labile-OH ligand that could bind to an apo-site serine residue with the aid of acid catalysis to yield the catalytically competent $\left[\mathbf{M o}^{\mathrm{VI}} \mathbf{O}(\mathbf{O R}) \mathbf{L}_{2}\right]^{-}$species in DMSOR. Since the ene-1,2-dithiolate ligand of $\left[\mathbf{M o}^{\mathrm{VI}} \mathbf{O}_{2} \mathbf{L}_{2}\right]^{\mathbf{2}}$ has -COOMe electron-withdrawing substituents, a strong organic acid such as CSA may be requested for protonation to the one oxide ligand of $\left[\mathbf{M o}^{\mathrm{VI}} \mathbf{O}_{2} \mathbf{L}_{2}\right]^{2-}$.

The reaction using $\left[\mathbf{M o}^{\mathrm{VI}} \mathbf{O}_{2} \mathbf{L}_{2}\right]^{2-}$ as a Moco model can be utilized to prepare other oxidoalcoholato-molybdenum(VI) derivatives. When 2-propanol and benzyl alcohol were employed in place of ethanol as the source of a monodentate ligand, the corresponding oxido-alcoholato-molybdenum(VI) derivatives, $\left[\mathbf{M o}^{\mathbf{V I}} \mathbf{O}(\boldsymbol{O} \mathbf{R}) \mathbf{L}_{2}\right]^{-}$, were obtained $\left(\mathrm{R}={ }^{\text {i }} \mathbf{P r}\right.$ and $\mathbf{C H}_{2} \mathbf{P h}$ ) at low temperature. These complexes were characterized by electronic absorption spectroscopy and CSI-mass spectrometry and are depicted in Figures S3 and S4, respectively. The solution $\left(\mathrm{C}_{2} \mathrm{H}_{5} \mathrm{CN}\right)$ absorption bands observed in the visible region of the spectrum are summarized in Table 2, where it can be seen that the two observed absorption bands vary slightly as a function of the nature of the alcoholato ligands. This overall similarity indicates that the electronic effects of the R groups are rather small.

In an effort to model relevant cofactor insertion chemistry in Type 1 DMSOR family enzymes (e.g. the periplasmic nitrate reductases, Nap) that possess a coordinated cysteine residue $^{1-4}$, we treated $\left[\mathbf{M o}^{\mathbf{V I}} \mathbf{O}_{2} \mathbf{L}_{2}\right]^{2-}$ with the organic acid CSA in the presence of a large excess of 1-hexanethiol in propionitrile at $-80{ }^{\circ} \mathrm{C}$. This resulted in the formation of a deepgray complex of [Mo $\left.\mathbf{M o}^{\mathrm{VI}} \mathbf{O}\left(S_{\mathbf{C}_{6}} \mathbf{H}_{13}\right) \mathbf{L}_{2}\right]^{-}$which we have characterized by electronic absorption spectroscopy and CSI-mass spectrometry (Figures 3 and S5). The absorption spectral changes from $\left[\mathbf{M o}^{\mathbf{V I}} \mathbf{O}_{2} \mathbf{L}_{2}\right]^{2-}$ to $\left[\mathbf{M o}^{\mathbf{V I}} \mathbf{O}\left(\mathbf{S C}_{\mathbf{6}} \mathbf{H}_{\mathbf{1 3}}\right) \mathbf{L}_{\mathbf{2}}\right]^{-}$proceeded with isosbestic points at 348, 461, 518, and $563 \mathrm{~nm}$ as shown in Figure S5 (a). The mass spectrum exhibited a peak cluster at $\mathrm{m} / z=642.9$ of which isotope distribution pattern is consistent with the calculated one as [Mo $\left.{ }^{\mathbf{V I}} \mathbf{O}\left(\mathbf{S C}_{\mathbf{6}} \mathbf{H}_{\mathbf{1 3}}\right) \mathbf{L}_{\mathbf{2}}\right]^{-}$(Figure S5 (b)). This complex is the first example of a bis(ene-1,2-dithiolato)oxido-thiolato-molybdenum(VI) complex. Many attempts to 
isolate the thiolate complex were unsuccessful because of very high solubility of the complex due to the long $-\mathrm{C}_{6} \mathrm{H}_{13}$ chain. As shown in Figure 3, coordination of the hexanethiolate ligand in place of the alcoholate ligand at the molybdenum(VI) center results in a significant bathochromic shift of the absorption bands in the visible region $\left(\lambda_{\max }=639\right.$ and $774 \mathrm{~nm}$ ). This suggests that the contribution of the thiolate ligand to the frontier orbitals is significant (vide infra).

\section{Crystal Structure of Oxido-ethanolato-molybdenum(VI) and DFT Optimized Structure of Oxido-ethanthiolato-molybdenum(VI)}

Single crystals of the oxido-ethanolato-molybdenum(VI) complex suitable for X-ray crystallography were obtained by recrystallization from acetone/diethyl ether at $-40{ }^{\circ} \mathrm{C}$ in the presence of a slight excess amount of $\mathrm{PPh}_{4} \mathrm{Br}$. The asymmetric unit consists of one $\mathrm{PPh}_{4}{ }^{+}$cation, one molybdenum(VI) complex anion, and one acetone molecule. The crystal structure of the anionic part is shown in Figure 4 (left). Selected bond lengths and angles are given in Table 3. The Mo1 atom is coordinated by one oxide oxygen atom (O1), one ethanolate oxygen atom $(\mathrm{O} 2)$, and four sulfur atoms $(\mathrm{S} 1-\mathrm{S} 4)$ from the two dithiolene ligands $\left(\mathrm{L}^{\mathrm{A}}\right.$ and $\mathrm{L}^{\mathrm{B}}$ ). The $\mathrm{S} 2-\mathrm{S} 1-\mathrm{S} 3-\mathrm{S} 4$ torsion angle describing the twist of the two dithiolene ligands is $105^{\circ}$, indicating a distorted octahedral geometry around the Mo center, resulting in the two dithiolene ligands being symmetry inequivalent. The geometry around the Mo center is more distorted than the molybdenum(VI) center of $\left[\mathrm{MoO}_{\mathbf{2}} \mathbf{L}_{\mathbf{2}}\right]^{\mathbf{2}}$ and is similar to that of $\left(\mathrm{Et}_{4} \mathrm{~N}\right)\left[\mathrm{Mo}^{\mathrm{VI}} \mathrm{O}\left(\mathrm{OSi}^{\mathrm{i}} \mathrm{Pr}_{3}\right) \mathrm{L}_{2}\right]$, which we have reported previously. ${ }^{26,47}$ However, the Mo1-O2-C13 bond angle of $134.6(10)^{\circ}$ is significantly smaller than the Mo$\mathrm{O}-\mathrm{Si}$ bond angle of $164.04(16)^{\circ}$. Furthermore, the $\mathrm{O} 1$ oxygen atom interacts with one of the acetone methyl groups through a hydrogen bond (3.16(3) $\AA$, Figure S7). This results in the Mo1-O1 bond length $(1.748(10) \AA)$ in $\left[\mathbf{M o}^{\mathbf{V I}} \mathbf{O}(\boldsymbol{O E t}) \mathbf{L}_{2}\right]^{-}$, being longer than that observed

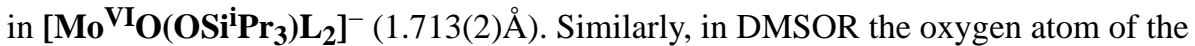
$\mathrm{Mo}^{\mathrm{VI}} \equiv \mathrm{O}$ moiety interacts with $\mathrm{Y} 114 \mathrm{OH}$ through hydrogen bonding. ${ }^{11}$ The Mo1-S4 bond length of 2.521(3) $\AA$ is significantly longer than the other three Mo-S bonds (2.396(3) for Mo1-S1, 2.464(4) for Mo1-S2, and 2.394(3) $\AA$ for Mo1-S3) due to the fact that S4 is oriented trans to the oxide oxygen atom, O1. The Mo1-S2 bond is also longer than the Mo1-S3 and Mo1-S3 bond due to trans influence of the ethoxide ligand. This asymmetric coordination mode of the four sulfur atoms is similar to that found in the crystal structure of DMSOR, where the two $\mathrm{S}$ atoms from one MPT ligand and one $\mathrm{S}$ atom from the another MPT ligand are at $2.4 \AA$ from the Mo center and the remaining Mo-S bond is at $3.1 \AA .{ }^{11}$ The trans influence due to the $\mathrm{O} 1$ atom is responsible for the observed differences between the coordinating ligands $\mathrm{L}^{\mathrm{A}}$ and $\mathrm{L}^{\mathrm{B}}$. The $\mathrm{S} 4$ atom on $\mathrm{L}^{\mathrm{B}}$ is oriented trans to $\mathrm{O} 1$ and possesses a S4-C8 bond that is significantly shorter (1.690(11) $\AA$ ) than that observed for the other three S-C bonds, which are oriented cis to O1 (S1-C1: 1.733(10), S2-C2: 1.724(12), and S3-C7: 1.750(10) $\AA$ ). As a result of the trans influence, the C7-C8 bond of $\mathrm{L}^{\mathrm{B}}$ is longer (1.374 (16) $\AA$ ) than the $\mathrm{C} 1-\mathrm{C} 2 \mathrm{C}=\mathrm{C}$ bond $\left(1.335(15) \AA\right.$ ) of the $\mathrm{L}^{\mathrm{A}}$ ligand. Interestingly, the C7-C9 bond in the $\mathrm{L}^{\mathrm{B}}$ ligand, 1.438(14) $\AA$, is shorter than that of the C8-C11 bond of 1.483(14) A. Regarding the orientation of the methyl ester moieties of $\mathrm{L}^{\mathrm{B}}$, the $-\mathrm{C} 11-\mathrm{O} 9-$ O10-C12 group trans to the oxide oxygen atom possesses an $89.70^{\circ}$ dihedral angle with respect to the chelating $\mathrm{S} 3-\mathrm{C} 7-\mathrm{C} 8-\mathrm{S} 4$ plane, while the dihedral angle consisting of the C9-O7-O8-C10 group oriented cis to $\mathrm{O} 1$ atom and the $\mathrm{S} 3-\mathrm{C} 7-\mathrm{C} 8-\mathrm{S} 4$ plane is markedly 
smaller $\left(6.44^{\circ}\right)$. Thus, differences in Mo-S $\mathrm{S}_{\text {dithiolene }}$ bond lengths appear to contribute to extended conjugation in $\mathrm{L}^{\mathrm{B}}$ and to a lesser extent in $\mathrm{L}^{\mathrm{A}}$, as shown in Scheme 2. In general, the computed metric parameters for $\left[\mathbf{M o}^{\mathbf{V I}} \mathbf{O}\left(\boldsymbol{O C}_{\mathbf{6}} \mathbf{H}_{13}\right) \mathbf{L}_{2}\right]^{-}$are in agreement with those determined from $\mathrm{x}$-ray crystallography.

We have not succeeded in obtaining single crystlas of $\left[\mathbf{M o}^{\mathrm{VI}} \mathbf{O}\left(\mathbf{S C}_{6} \mathbf{H}_{13}\right) \mathbf{L}_{2}\right]^{-}$. Thus, we have determined the molecular structure of this complex using DFT methods in order to make initial comparisons with the X-ray crystal structure of $\left[\mathbf{M o}^{\mathbf{V I}} \mathbf{O}(\boldsymbol{O E t}) \mathbf{L}_{2}\right]^{-}$. In these calculations, an ethanethiolate ligand has been used in place of the 1-hexanethiolate ligand and the optimized structure is presented in Figure 4 (right). The relevant bond lengths, bond angles, and the O1-Mo1-S5-C13 dihedral angle are given in Table 3 for comparison with $\left[\mathbf{M o}^{\mathrm{VI}} \mathbf{O}(\boldsymbol{O E t}) \mathbf{L}_{2}\right]^{-}$. The Mo center exhibits a distorted octahedral geometry as observed for structurally characterized $\left[\mathbf{M o}^{\mathrm{VI}} \mathbf{O}(\boldsymbol{O E t}) \mathbf{L}_{2}\right]^{-}$. The calculated Mo- $\mathrm{S}_{\text {thiolate }}$ bond length (Mo1-S5) of $2.42 \AA$ is comparable to that observed in $\mathrm{Tp}^{*} \mathrm{Mo}^{\mathrm{VI}} \mathrm{O}_{2}\left(\mathrm{SC}_{6} \mathrm{H}_{5}\right)\left(2.398 \AA, \mathrm{Tp}^{*}=\right.$ Hydrotris(3,5-dimethyl-pyrazolyl)borate) and longer than the Mo- $\mathrm{S}_{\text {thiolate }}$ bond (2.380 $\AA$ ) in the monooxido $\mathrm{Mo}(\mathrm{V})$ dithiolene compound [(L3S) $\mathrm{MoO}(\mathrm{bdt})](\mathrm{bdt}=$ benzene-1,2dithiolate; L3SH = (2-dimethylethanethiol)-bis-(3,5-dimethylpyrazolyl)methane). ${ }^{53,54}$ The $\mathrm{Mo}(1)-\mathrm{S}(4)$ distance is computed to be quite long $(2.61 \AA)$ and comparable to that observed experimentally in $\mathrm{Mo}^{\mathrm{VI}} \mathrm{O}_{\mathbf{2}}(\mathrm{OEt})_{2} \mathbf{L}_{\mathbf{2}}$.

\section{Electronic Structure of Oxido-ethanolato- and Oxido-ethanthiolato-molybdenum(VI) Complexes}

A key question remains regarding why specific amino acid ligands bind to certain classes of DMSOR family enzymes, particularly with respect to how this ligation contributes to the underpinning electronic structure that contributes to their unique reactivities. Our studies on the isostructural $\left[\mathbf{M o}^{\mathbf{V I}} \mathbf{O}(\boldsymbol{O E t}) \mathbf{L}_{2}\right]^{-}$and $\left[\mathbf{M o}^{\mathbf{V I}} \mathbf{O}(\mathbf{S E t}) \mathbf{L}_{2}\right]^{-}$pair provides support for a

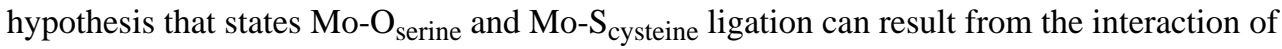
these amino acid donors with $\mathrm{MoO}(\mathrm{MPT})_{2}$ Moco precursors, and further allows us to examine the effects of ancillary ligand (-OR, -SR) coordination on the electronic structures of these complexes at parity of the remaining coordination sphere.

The electronic absorption spectrum of $\left[\mathbf{M o}^{\mathbf{V I}} \mathbf{O}(\boldsymbol{O E t}) \mathbf{L}_{2}\right]^{-}(742 \mathrm{~nm}$ and $539 \mathrm{~nm})$ is remarkably similar to that of oxidized DMSO reductase $(717 \mathrm{~nm}$ and $549 \mathrm{~nm})$, and to what we have previously observed for $\left.\left[\mathrm{Mo}^{\mathrm{VI}} \mathrm{O}(\mathrm{OBz}) \text { (cyclohexene-1,2-dithiolate }\right)_{2}\right]^{-}(807 \mathrm{~nm}$ and $597 \mathrm{~nm})$ and $\left[\mathbf{M o}^{\mathbf{V I}} \mathbf{O}\left(\mathbf{O S i}^{i} \mathbf{P r}_{\mathbf{3}}\right) \mathbf{L}_{\mathbf{2}}\right]^{-}(739 \mathrm{~nm}$ and $568 \mathrm{~nm}) .{ }^{55,47}$ Our bonding calculations show that a cis $\mathrm{S}\left(\mathrm{p}_{\mathrm{z}}\right)$ orbital on $\mathrm{L}^{\mathrm{B}}$ and an $\mathrm{O}(\mathrm{p})$ orbital from the alcoholate form $\mathrm{d}-\mathrm{p} \pi$ bonding interactions with the $\mathrm{Mo}\left(\mathrm{d}_{\mathrm{xy}}\right)$ redox orbital which, for the $\mathrm{Mo}(\mathrm{VI})$ state, is the acceptor orbital (LUMO) in these low-energy LMCT transitions. The relevant Kohn-Sham orbitals for $\left[\mathbf{M o}^{\mathbf{V I}} \mathbf{O}(\boldsymbol{O E t}) \mathbf{L}_{2}\right]^{-}$are given in Figure S8. Using a combination of timedependent DFT computations and our previous band assignments for $\left[\mathbf{M o}^{\mathbf{V I}} \mathbf{O}\left(\mathbf{O S i}^{i} \mathbf{P r}_{3}\right) \mathbf{L}_{2}\right]^{-}$ and $\left.\left[\mathrm{Mo}^{\mathrm{VI}} \mathrm{O}(\mathrm{OBz}) \text { (cyclohexene-1,2-dithiolato }\right)_{2}\right]^{-}$, we can reasonably assign the lowest energy band as primarily arising from a HOMO $\rightarrow$ LUMO one-electron promotion (92\%) with dominant $\mathrm{L}^{\mathrm{A}} \rightarrow\left(\mathrm{Mod}_{\mathrm{xy}}+\mathrm{O} 2 \pi\right)$ charge transfer character. Band 2 primarily derives from a HOMO-1 $\rightarrow$ LUMO one-electron promotion $(72 \%)$ and possesses dominant $\left(\mathrm{L}^{\mathrm{A}}+\right.$ $\left.\mathrm{L}^{\mathrm{B}}\right) \rightarrow\left(\mathrm{Mo} \mathrm{d}_{\mathrm{xy}}+\mathrm{O} 2 \pi\right)$ CT charge transfer character. The two LMCT bands in 
$\left[\mathbf{M o}{ }^{\mathbf{V I}} \mathbf{O}(\boldsymbol{O E t}) \mathbf{L}_{2}\right]^{-}$are computed to occur at $755 \mathrm{~nm}$ and $511 \mathrm{~nm}$, and the nature of these two ligand-to-metal charge transfer (LMCT) transitions is further illuminated in the calculated electron density difference maps (EDDMs) for Bands 1 and 2 (Figure 5).

As mentioned previously, the LMCT bands observed for $\left[\mathbf{M o}^{\mathbf{V I}} \mathbf{O}(\boldsymbol{S E t}) \mathbf{L}_{\mathbf{2}}\right]^{-}(774 \mathrm{~nm}$ and $639 \mathrm{~nm})$ are red-shifted relative to $\left[\mathbf{M o}^{\mathbf{V I}} \mathbf{O}(\boldsymbol{O E t}) \mathbf{L}_{2}\right]^{-}$, indicating a significant contribution from the coordinated thiolate to these transitions. We tentatively assign the $774 \mathrm{~nm}$ band as primarily arising from a HOMO $\rightarrow$ LUMO one-electron promotion (90\%) with dominant $\mathrm{L}^{\mathrm{A}}+\mathrm{L}^{\mathrm{B}} \rightarrow\left(\mathrm{Mod}_{\mathrm{xy}}+\mathrm{S} 3 \pi\right)$ charge transfer character. Band 2 primarily derives from a HOMO-1 $\rightarrow$ LUMO one-electron promotion (71\%) and possesses dominant $\left(\mathrm{L}^{\mathrm{A}}+\mathrm{S} 3 \pi\right) \rightarrow$ $\left(\mathrm{Mo} \mathrm{d}_{\mathrm{xy}}+\mathrm{L}^{\mathrm{B}}\right) \mathrm{CT}$ charge transfer character. The two LMCT bands in $\left[\mathbf{M o}^{\mathbf{V I}} \mathbf{O}(\mathbf{S E t}) \mathbf{L}_{\mathbf{2}}\right]^{-}$are computed to occur at $790 \mathrm{~nm}$ and $557 \mathrm{~nm}$, and the nature of these LMCT transitions is depicted in their respective calculated electron density difference maps (EDDMs) in Figure 6. The relevant Kohn-Sham orbitals for $\left[\mathbf{M o}^{\mathbf{V I}} \mathbf{O}(\mathbf{S E t}) \mathbf{L}_{2}\right]^{-}$are given in Figure S9.

The analysis of the electronic absorption spectra for $\left[\mathbf{M o}^{\mathbf{V I}} \mathbf{O}(\boldsymbol{O E t}) \mathbf{L}_{2}\right]^{-}$and $\left[\mathbf{M o}{ }^{\mathrm{VI}} \mathbf{O}(\mathbf{S E t}) \mathbf{L}_{2}\right]^{-}$reveal key differences between alkoxide and thiolate ligation in these systems and allow for a critical analysis of the electronic structure differences between DMSOR family enzymes that possess cysteine or serine ligation. Namely, band 2 supports an increase in Mo- $E R$ covalency for $\left[\mathbf{M o}^{\mathbf{V I}} \mathbf{O}(S \mathbf{E t}) \mathbf{L}_{2}\right]^{-}$compared to $\left[\mathbf{M o}{ }^{\mathbf{V I}} \mathbf{O}(\boldsymbol{O E t}) \mathbf{L}_{2}\right]^{-}$due to (1) the markedly lower energy of the LMCT transition indicating an increase in EEt $\rightarrow$ $\operatorname{Mo}(\mathrm{xy}) \mathrm{LMCT}$ character for $\left[\mathbf{M o}^{\mathbf{V I}} \mathbf{O}(\boldsymbol{S E t}) \mathbf{L}_{2}\right]^{-}$, (2) the increased oscillator strength for this transition, and (3) the $E \mathrm{Et} \rightarrow \mathrm{Mo}(\mathrm{xy})$ electron donor character present in the EDDM for band 2 for $\left[\mathbf{M o}^{\mathbf{V I}} \mathbf{O}(\mathbf{S E t}) \mathbf{L}_{2}\right]^{-}$that is not present in $\left[\mathbf{M o}^{\mathbf{V I}} \mathbf{O}(\boldsymbol{O E t}) \mathbf{L}_{2}\right]^{-}$. The nature of the distorted $\mathrm{O}_{\mathrm{h}}$ geometry in these $\left[\mathbf{M o}^{\mathbf{V I}} \mathbf{O}(\boldsymbol{E E t}) \mathbf{L}_{2}\right]^{-}(E=\mathrm{O}, \mathrm{S})$ compounds and in DMSOR is also of keen interest since this geometry results in a LUMO wavefunction that possesses strong $\pi^{*}$ interactions between the $\operatorname{Mo}\left(\mathrm{d}_{\mathrm{xy}}\right)$ redox orbital and the cis $\mathrm{S}\left(\mathrm{p}_{\mathrm{z}}\right)$ ene-1,2-dithiolate orbital localized on the equatorial $\mathrm{L}^{\mathrm{B}}$ sulfur donor. The presence of covalent Mo-ene-1,2dithiolate (S3) bonding interaction in these monooxido molybdenum(VI) compounds is reflected in the nature of their low energy LMCT transitions and this bonding interaction has previously been hypothesized to provide an ene-1,2-dithiolate mediated pathway for enzymatic electron transfer regeneration of the reduced enzyme involving only one of the pyranopterin ene-1,2-dithiolate. ${ }^{55} \mathrm{~A}$ second important d-p $\pi$ bonding interaction derives from the $\sim 180^{\circ} \mathrm{O}_{\text {oxo }}-\mathrm{Mo}-E-\mathrm{C}$ dihedral angle involving the alcoholate and thiolate donors. In this geometry the in-plane $E(\mathrm{p})$ orbital is properly oriented for good $\pi$ overlap with the $\mathrm{Mo}(\mathrm{xy})$ orbital. For $\left[\mathbf{M o}^{\mathbf{V I}} \mathbf{O}(\boldsymbol{O E t}) \mathbf{L}_{2}\right]^{-}$, the $\mathrm{O}_{\text {oxo }}-\mathrm{Mo}^{-} \mathrm{O}_{\mathrm{OEt}}-\mathrm{C}$ dihedral angle is $171^{\circ}$, while for $\left[\mathbf{M o}^{\mathrm{VI}} \mathbf{O}(\mathbf{S E t}) \mathbf{L}_{2}\right]^{-}$the $\mathrm{O}_{\mathrm{oxo}^{-}}-\mathrm{Mo}-\mathrm{S}_{\mathrm{SEt}}{ }^{-} \mathrm{C}$ dihedral angle is computed to be $175^{\circ}$. Interestingly, the larger Mo-S $\mathrm{S}_{\text {thiolate }} \pi^{*}$ interaction relative to the $\mathrm{Mo-} \mathrm{O}_{\text {alkoxide }} \pi^{*}$ bonding interactions in the LUMOs of $\left[\mathbf{M o}^{\mathbf{V I}} \mathbf{O}(\boldsymbol{E E t}) \mathbf{L}_{2}\right]^{-}$and $\left[\mathbf{M o}^{\mathbf{V I}} \mathbf{O}(\boldsymbol{O E t}) \mathbf{L}_{2}\right]^{-}$do not appear to occur at the expense of the dithiolene contributions to these LUMOs (Table 4). There is an $\sim 50 \%$ increase in the $E$ contribution to the $\left[\mathbf{M o}^{\mathbf{V I}} \mathbf{O}(\boldsymbol{E E t}) \mathbf{L}_{2}\right]^{-}$LUMO as $E=\mathrm{O}$ is replaced by $E=\mathrm{S}$, an $\sim 500 \%$ increase in the $E$ contribution to the HOMO orbital, and an $\sim 400 \%$ increase in the $E$ contribution to the HOMO-1 orbital. This results in $\sim 36 \%$ more $S E \mathrm{E} S$ character in the valence MOs of $\left[\mathbf{M o}^{\mathbf{V I}} \mathbf{O}(\mathbf{S E t}) \mathbf{L}_{2}\right]^{-}$relative to the $O$ Et $\mathrm{O}$ character in $\left[\mathbf{M o}^{\mathrm{VI}} \mathbf{O}(\boldsymbol{O E t}) \mathbf{L}_{2}\right]^{-}$, and this derives from the greater electron donating ability of the thiolate 
compared to the alkoxide. The dramatic increase in the thiolate character present in the $\left[\mathbf{M o}^{\mathbf{V I}} \mathbf{O}(\mathbf{S E t}) \mathbf{L}_{2}\right]^{-}$HOMO-1 and LUMO orbitals relative to the alkoxide character in $\left[\mathbf{M o}^{\mathrm{VI}} \mathbf{O}(\boldsymbol{O E t}) \mathbf{L}_{2}\right]^{-}$underscores a key difference in the contributions of these donors to the electronic structures of these $\left[\mathbf{M o}^{\mathbf{V I}} \mathbf{O}(\boldsymbol{E E t}) \mathbf{L}_{2}\right]^{-}$compounds. This clearly highlights the importance of serine and cysteine ligation in different DMSOR family enzymes for controlling the effective nuclear charge of the active site Mo ion and modulating the enzyme reduction potential.

\section{CONCLUSION}

In summary, we have demonstrated that the anionic bis(ene-1,2-dithiolato)dioxidomolybdenum(VI) complex, [Mo $\left.{ }^{\mathbf{V I}} \mathbf{O}_{2} \mathbf{L}_{2}\right]^{2-}$, is smoothly converted to oxido-alcoholato- and oxido-thiolato-molybdenum(VI) complexes, $\left[\mathbf{M o}^{\mathbf{V I}} \mathbf{O}(\boldsymbol{E} \mathbf{E t}) \mathbf{L}_{2}\right]^{-}(E=\mathrm{O}, \mathrm{S})$, by the reaction with the corresponding alcohol and thiol in the presence of an organic acid at low temperature. The oxido-ethanolato-molybdenum(VI) complex is the first crystallographically characterized example of a bis(ene-1,2-dithiolato)oxido-alcoholatomolybdenum(VI) complex. The substitution of one oxide ligand by the alcohol or thiol is initiated by the protonation of the terminal oxide ligand (Scheme 1). Importantly, the oxidomolybdenum(IV) complex possessing identical ene-1,2-dithiolate ligands is unreactive under the same conditions. We therefore suggest that the active sites of DMSOR family enzymes DMSO reductase and nitrate reductase may be generated by the acid catalyzed reaction of a $\mathrm{Mo}^{\mathrm{VI}} \mathrm{O}_{2}$ from of the cofactor with an active site serine or a cysteine residue, respectively. The generated $\mathrm{Mo}^{\mathrm{VI}} \mathrm{O}(\mathrm{O} \cdot \mathrm{Ser})$ and $\mathrm{Mo}^{\mathrm{VI}} \mathrm{O}(\mathrm{S} \cdot \mathrm{Cys})$ species may be reduced by electron transfer proteins via a proton coupled electron transfer reaction to yield the desoxidomolybdenum(IV) state, which is then poised to abstract an oxygen atom from DMSO or $\mathrm{NO}_{3}{ }^{-}$, respectively. We have also shown that there are potentially significant electronic structure differences that arise from thiolate (cysteine) and from alkoxide (serine) coordination to an oxomolybdenum(VI) site. Our spectroscopic and computational studies show that there is a markedly greater $\mathrm{S}_{\text {thiolate }} \rightarrow \mathrm{Mo}(\mathrm{VI})$ charge donation in $\left[\mathbf{M o}^{\mathbf{V I}} \mathbf{O}(\boldsymbol{S E t}) \mathbf{L}_{2}\right]^{-}$compared to the $\mathrm{O}_{\text {alkoxide }} \rightarrow \mathrm{Mo}(\mathrm{VI})$ charge transfer in $\left[\mathbf{M o}^{\mathbf{V I}} \mathbf{O}(\boldsymbol{O E t}) \mathbf{L}_{2}\right]^{-}$, as evidenced by the nature of the HOMO-1 $\rightarrow$ LUMO one-electron promotion contribution to Band 2 in $\left[\mathbf{M o}^{\mathbf{V I}} \mathbf{O}(\mathbf{S E t}) \mathbf{L}_{2}\right]^{-}$. These ancillary ligand interactions in DMSOR family enzymes are likely to play disparate roles in how effectively they can buffer the effective nuclear charge of the metal, leading to differences in how they contribute to redox potential modulation of the catalytic site during the course of catalysis.

\section{Supplementary Material}

Refer to Web version on PubMed Central for supplementary material.

\section{Acknowledgments}

This work was supported by grants (No. 24109015, Stimuli-responsive Chemical Species and No. 22105007, Molecular activation) for Scientific Research on Innovative Areas from MEXT of Japan. M.L.K. gratefully acknowledges the support of this research by the National Institutes of Health (Grant No. GM--057378 to MLK). 


\section{References}

1. Romao MJ. Dalton Trans. 2009; 38:4053-4068. [PubMed: 19452052]

2. Hille R. Dalton Trans. 2013; 42:3029-3042. [PubMed: 23318732]

3. Hille R, Basu P. Chem Rev. 2014; 114:3963-4038. [PubMed: 24467397]

4. Kirk, ML.; Stein, B. Comprehensive Inorganic Chemistry II. 2. Jan, R.; Kenneth, P., editors. Elsevier; Amsterdam: 2013. p. 263

5. Sparacino-Watkins C, Stolz JF, Basu P. Chem Soc Rev. 2014; 43:676-706. [PubMed: 24141308]

6. Mendel RR. Plant Cell Rep. 2011; 30:1787-1797. [PubMed: 21660547]

7. Mendel RR, Schwarz G. Coord Chem Rev. 2011; 255:1145-1158.

8. Mendel RR, Kruse T. Biochimica et Biophysica Acta. 2012; 1823:1568-1579. [PubMed: 22370186]

9. Temple CA, Rajagopalan KV. J Biol Chem. 2000; 275:40202-40210. [PubMed: 10978348]

10. Mendel RR, Leimkuhler S. J Biol Inorg Chem. 2015; 20:337-347. [PubMed: 24980677]

11. Schindelin H, Kisker C, Hilton J, Rajagopalan KV, Rees DC. Science. 1996; 272:1615-1621. [PubMed: 8658134]

12. Li H-K, Temple C, Rajagopalan KV, Schindelin H. J Am Chem Soc. 2000; 122:7673-7680.

13. Dias JM, Than ME, Humm A, Huber R, Bourenkov GP, Bartunik HD, Bursakov S, Calvete J, Caldeira J, Carneiro C, Moura JJG, Moura I, Romao MJ. Structure. 1999; 7:65-79. [PubMed: 10368307]

14. Boyington JC, Gladyshev VN, Khangulov SV, Stadtman TC, Sun PD. Science. 1997; 275:13051308. [PubMed: 9036855]

15. Enemark JH, Cooney JJA, Wang JJ, Holm RH. Chem Rev. 2004; 104:1175-1200. [PubMed: 14871153]

16. McMaster J, Tunney JM, Garner CD. Prog Inorg Chem. 2004; 52:539.

17. Sugimoto H, Tsukube H. Chem Soc Rev. 2008; 37:2609-2800. [PubMed: 19020675]

18. Hine FJ, Taylor AJ, Garner CD. Coord Chem Rev. 2010; 254:1570-1579.

19. Holm HH, Solomon EI, Majumdar A, Tenderholt A. Coord Chem Rev. 2011; 255:993-1015.

20. Lim BS, Donahue JP, Holm RH. Inorg Chem. 2000; 39:263-273. [PubMed: 11272534]

21. Lim BS, Sung KM, Holm RH. J Am Chem Soc. 2000; 122:7410-7411.

22. Lim BS, Holm RH. J Am Chem Soc. 2001; 123:1920-1930. [PubMed: 11456813]

23. Wang JJ, Kryatova OP, Rybak-Akimova EV, Holm RH. Inorg Chem. 2004; 43:8092-8101. [PubMed: 15578849]

24. Wang JJ, Tessier C, Holm RH. Inorg Chem. 2006; 45:2979-2988. [PubMed: 16562954]

25. Coucouvanis D, Hadjikyriacou A, Toupadakis A, Koo SM, Ileperuma O, Draganjac M, Salifoglou A. Inorg Chem. 1991; 30:754-767.

26. Sugimoto H, Tatemoto S, Suyama K, Miyake H, Itoh S, Dong C, Yang J, Kirk ML. Inorg Chem. 2009; 48:10581-10590. [PubMed: 19831360]

27. Frisch, MJ.; Trucks, GW.; Schlegel, HB.; Scuseria, GE.; Robb, MA.; Cheeseman, JR.; Scalmani, G.; Barone, V.; Mennucci, B.; Petersson, GA.; Nakatsuji, H.; Caricato, M.; Li, X.; Hratchian, HP.; Izmaylov, AF.; Bloino, J.; Zheng, G.; Sonnenberg, JL.; Hada, M.; Ehara, M.; Toyota, K.; Fukuda, R.; Hasegawa, J.; Ishida, M.; Nakajima, T.; Honda, Y.; Kitao, O.; Nakai, H.; Vreven, T.; Montgomery, JA., Jr; Peralta, JE.; Ogliaro, F.; Bearpark, M.; Heyd, JJ.; Brothers, E.; Kudin, KN.; Staroverov, VN.; Kobayashi, R.; Normand, J.; Raghavachari, K.; Rendell, A.; Burant, JC.; Iyengar, SS.; Tomasi, J.; Cossi, M.; Rega, N.; Millam, JM.; Klene, M.; Knox, JE.; Cross, JB.; Bakken, V.; Adamo, C.; Jaramillo, J.; Gomperts, R.; Stratmann, RE.; Yazyev, O.; Austin, AJ.; Cammi, R.; Pomelli, C.; Ochterski, JW.; Martin, RL.; Morokuma, K.; Zakrzewski, VG.; Voth, GA.; Salvador, P.; Dannenberg, JJ.; Dapprich, S.; Daniels, AD.; Farkas, Ö.; Foresman, JB.; Ortiz, JV.; Cioslowski, J.; Fox, DJ. Gaussian 09, Revision C.1. Gaussian, Inc; Wallingford CT: 2009.

28. Perdew JP, Burke K, Ernzerhof M. Phys Rev Lett. 1996; 77:3865-3868. [PubMed: 10062328] 29. Perdew JP, Burke K, Ernzerhof M. Phys Rev Lett. 1997; 78:1396.

30. Weigend F, Ahlrichs R. Phys Chem Chem Phys. 2005; 7:3297-3305. [PubMed: 16240044]

31. Andrae D, Haeussermann U, Dolg M, Stoll H, Preuss H. Theor Chim Acta. 1990; 77:123-141. 
32. Feller D. J Comp Chem. 1996; 17:1571-1586.

33. Schuchardt KL, Didier BT, Elsethagen T, Sun L, Gurumoorthi V, Chase J, Li J, Windus TL. J

Chem Inf Model. 2007; 47:1045-1052. [PubMed: 17428029]

34. Mulliken RS. J Chem Phys. 1955; 23:1833-1840.

35. Bauernschmitt R, Ahlrichs R. Chem Phys Lett. 1996; 256:454-464.

36. Casida ME, Jamorski C, Casida KC, Salahub DR. J Chem Phys. 1998; 108:4439-4449.

37. Gorelsky, SI. AOMix: Program for Molecular Orbital Analysis. 2015. http://www.sg-chem.net/, version 6.51

38. Gorelsky SI, Lever ABP. J Organomet Chem. 2001; 635:187-196.

39. Stratmann RE, Scuseria GE, Frisch MJ. J Chem Phys. 1998; 109:8218-8224.

40. Van Caillie C, Amos RD. Chem Phys Lett. 1999; 308:249-255.

41. Van Caillie C, Amos RD. Chem Phys Lett. 2000; 317:159-164.

42. Furche F, Ahlrichs R. J Chem Phys. 2002; 117:7433-7444.

43. Scalmani G, Frisch MJ, Mennucci B, Tomasi J, Cammi R, Barone V. J Chem Phys. 2006; 124:1.

44. Burla MC, Caliandro R, Camalli M, Carrozzini B, Cascarano GL, Giacovazzo C, Mallamo M, Mazzone A, Polidori G, Spagna R. J Appl Cryst. 2012; 45:357-361.

45. Crystal Structure 3.8: Crystal Structure Analysis Package, Rigaku Corporation (2000-2006) 9009 New Trails Dr. The Woodlands TX 77381 USA

46. The reaction carried out at room temperature resulted in complicated changes.

47. Sugimoto H, Tatemoto S, Suyama K, Miyake H, Mtei RP, Itoh S, Kirk ML. Inorg Chem. 2010; 49:5368-5370. [PubMed: 20491454]

48. The complex, $\mathbf{M o}^{\mathbf{V I}} \mathbf{O}\left(\mathbf{O S i}{ }^{\mathbf{i}} \mathbf{P r}_{3}\right) \mathbf{L}$ has been prepared by oxygen atom transfer from $\mathrm{Me}_{3} \mathrm{NO}$ to the $\mathbf{M o}^{\text {IV }}\left(\mathbf{O S i}^{\mathbf{i}} \mathbf{P r}_{3}\right) \mathbf{L}^{47}$

49. Das SK, Chaudhury PK, Biswas D, Sarkat S. Inorg Chem. 1994; 116:9061-9070.

50. Ueyama N, Oku H, Kondo M, Okamura T, Yoshinaga N, Nakamura A. Inorg Chem. 1996; 35:643650 .

51. Sugimoto H, Tarumizu M, Tanaka K, Miyake H, Tsukube H. Dalton Trans. 2005:3558-3565. [PubMed: 16234938]

52. Donahue JP, Goldsmith CR, Nadiminti U, Holm RH. J Am Chem Soc. 1998; 120:12869-12882.

53. Xiao Z, Bruck MA, Doyle C, Enemark J, Grittini C, Gable RW, Wedd AG, Young CG. Inorg Chem. 1995; 34:5950-5962.

54. K, Chohan BS, Carrano CJ, Kirk ML. Inorg Chem. 2003; 42:6194-6203. [PubMed: 14514295]

55. Sugimoto H, Sato M, Giles LJ, Asano K, Suzuki T, Kirk ML, Itoh S. Dalton Trans. 2013; 42:15927-15930. [PubMed: 24029827] 


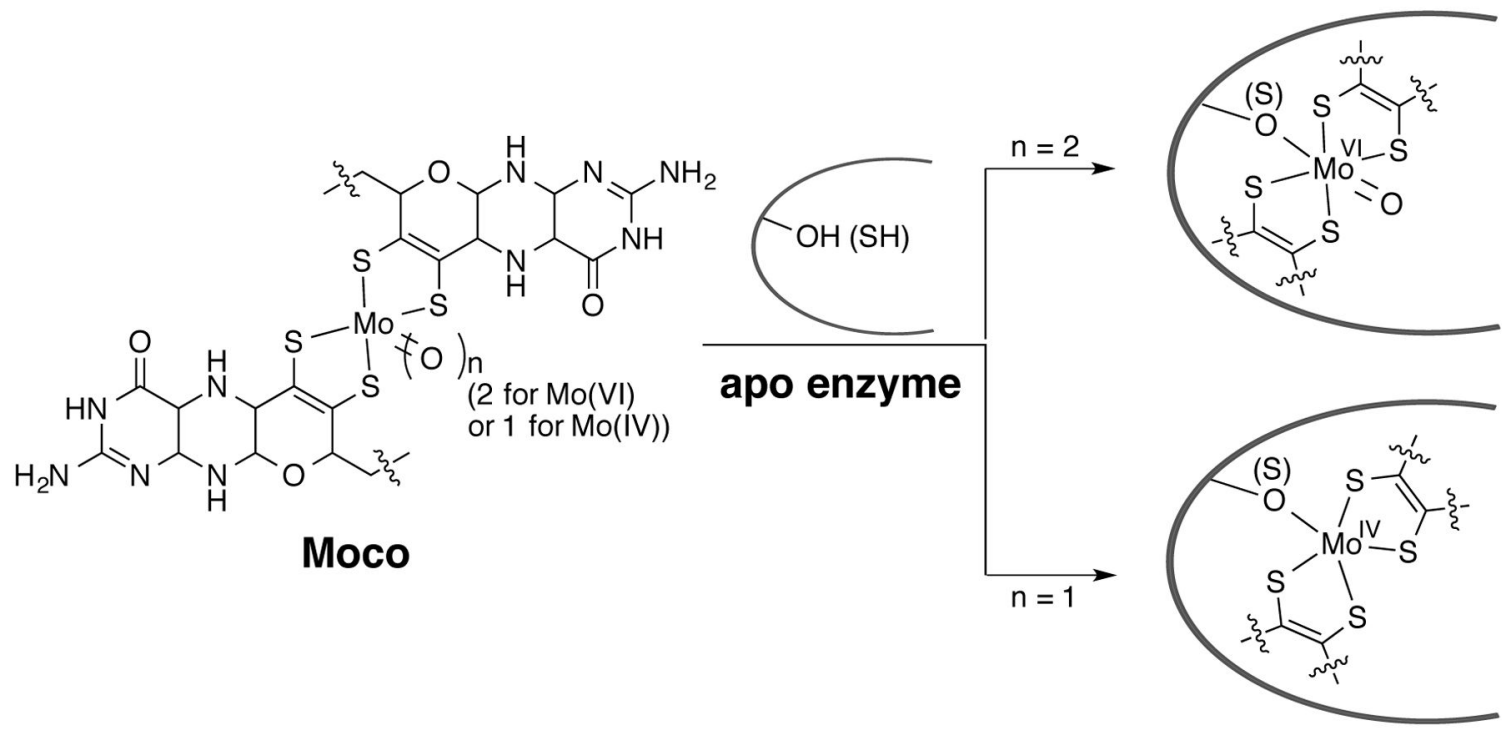

Active Site

Figure 1.

Proposed formation step of the active site of DMSO reductase family enzymes. 
(a)

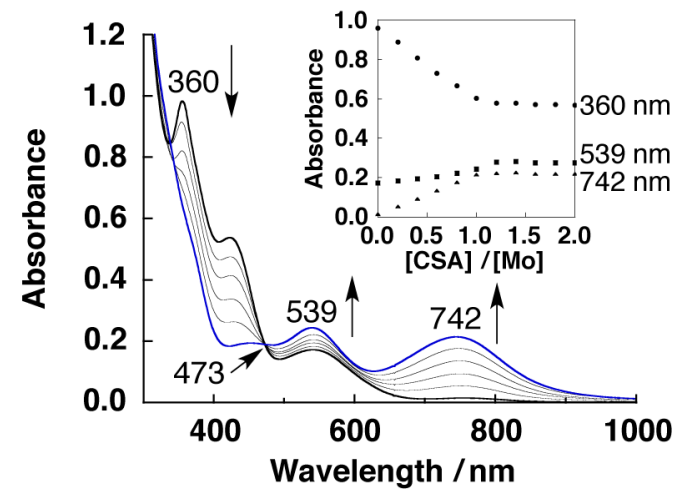

(b)

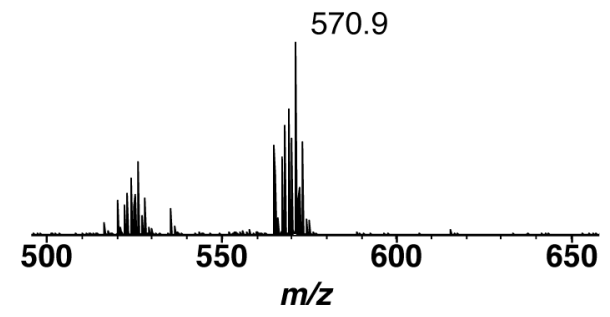

Figure 2.

(a) UV-vis spectral changes for the titration of $\left[\mathbf{M o} \mathbf{V I}_{\mathbf{2}} \mathbf{O}_{\mathbf{2}} \mathbf{L}_{\mathbf{2}}\right]^{\mathbf{2}}(0.10 \mathrm{mM})$ with 10 camphorsulfonic acid in propionitrile containing $0.5 \%$ ethanol $(0.86 \mathrm{mM})$ at $-60{ }^{\circ} \mathrm{C}$; (inset) plots of the absorbance at 360, 539, and $742 \mathrm{~nm}$ against the molar ratio of [CSA]/[Mo], (b) CSI-mass spectrum of the final solution mixture taken at $-60{ }^{\circ} \mathrm{C}$. 


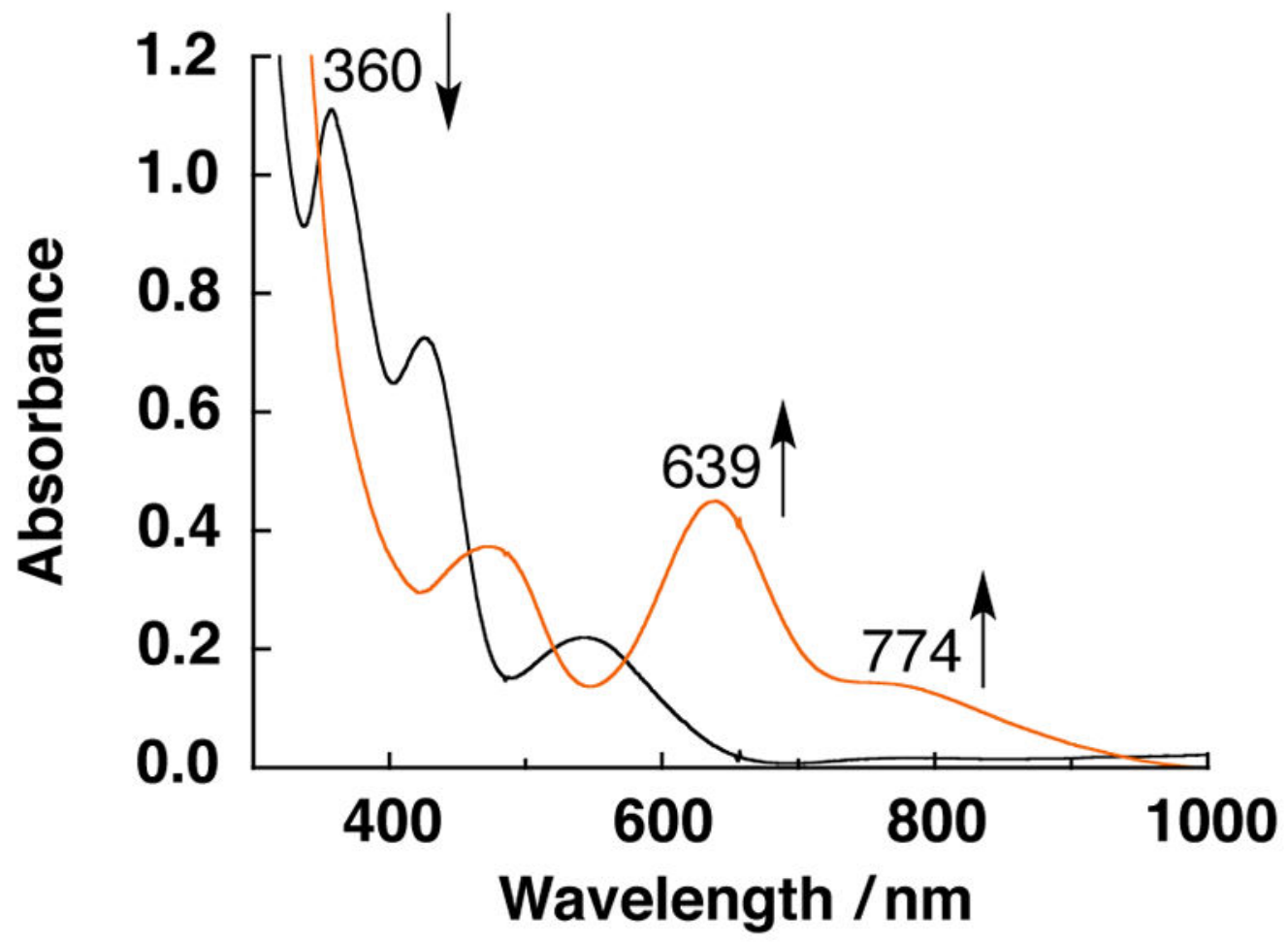

Figure 3.

UV-vis spectral change for the conversion of $\left[\mathbf{M o}^{\mathbf{V I}} \mathbf{O}_{2} \mathbf{L}_{2}\right]^{2-}$ (black, $0.10 \mathrm{mM}$ ) to

$\left[\mathrm{Mo}^{\mathrm{VI}} \mathrm{O}\left(\mathrm{SC}_{6} \mathbf{H}_{13}\right) \mathbf{L}_{2}\right]^{-}$(orange) by addition of 1 equiv. of 10-camphorsulfonic acid in propionitrile containing a large excess 1 -hexanethiol $(100 \mathrm{mM})$ at $-80{ }^{\circ} \mathrm{C}$. 


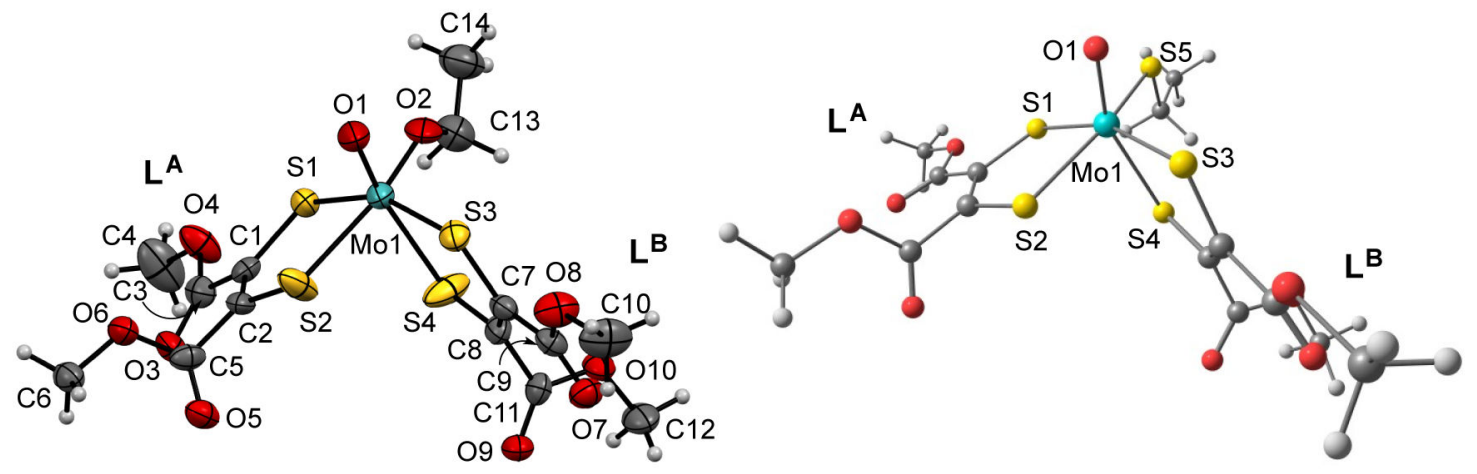

Figure 4.

Left: Crystal structure of the anionic part of $\left(\mathrm{PPh}_{4}\right)\left[\mathrm{Mo}^{\mathrm{VI}} \mathrm{O}(O \mathrm{Et}) \mathrm{L}_{2}\right] \cdot$ acetone with thermal ellipsoids at the $50 \%$ probability level. Right: DFT-optimized structure of [Mo $\left.{ }^{\mathbf{V I}} \mathbf{O}(\mathbf{S E t}) \mathbf{L}_{2}\right]^{-}$ (def2-tzvp basis set). 
(A)

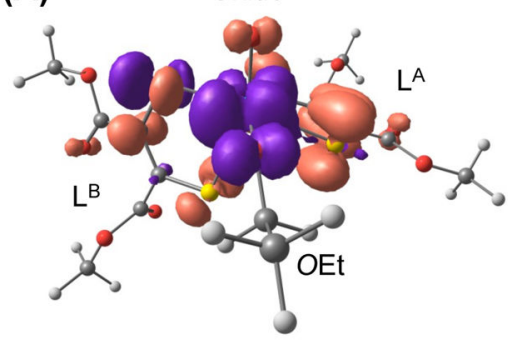

(B)

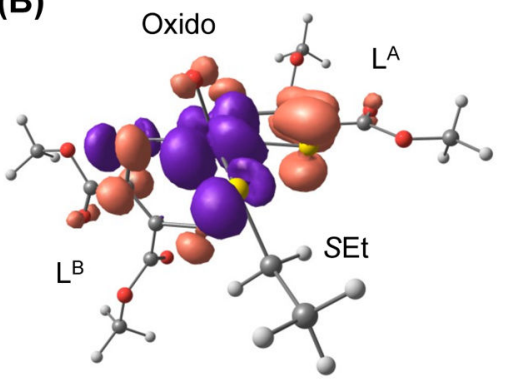

Figure 5.

Electron density difference map (EDDM) for the transition that is responsible for band 1 $\left[\mathrm{HOMO} \rightarrow\right.$ LUMO] in $\left[\mathbf{M o}^{\mathbf{V I}} \mathbf{O}(\boldsymbol{O E t}) \mathbf{L}_{2}\right]^{-}$(A) and $\left[\mathbf{M o}^{\mathbf{V I}} \mathbf{O}(\boldsymbol{S E t}) \mathbf{L}_{2}\right]^{-}(\mathrm{B})$. The density value of the plot is 0.002 . The oscillator strength for this transition is calculated to be $\mathrm{f}=0.0203$ and $\mathrm{f}=0.0266$ for (A) and (B), respectively. Red indicates a loss of electron density in the transition, and blue indicates a gain in electron density for the transition. 
(A)

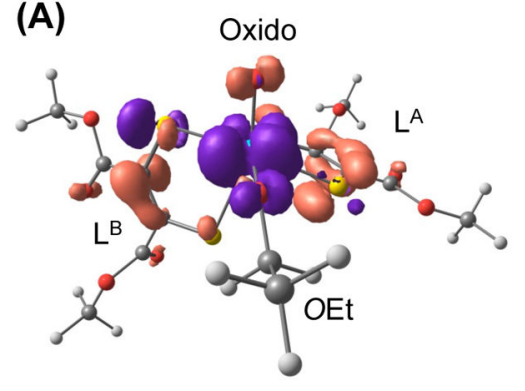

(B)

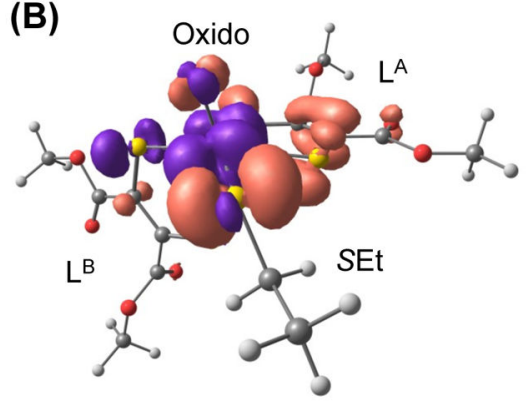

Figure 6.

Electron density difference map (EDDM) for the transition that is responsible for band 2 $[\mathrm{HOMO}-1 \rightarrow \mathrm{LUMO}]$ in $\left[\mathbf{M o}^{\mathbf{V I}} \mathbf{O}(\boldsymbol{O E t}) \mathbf{L}_{2}\right]^{-}(\mathrm{A})$ and $\left[\mathbf{M o}{ }^{\mathbf{V I}} \mathbf{O}(\boldsymbol{S E t}) \mathbf{L}_{\mathbf{2}}\right]^{-}(\mathrm{B})$. The density value of the plot is 0.002 . The oscillator strength for this transition is calculated to be $\mathrm{f}=$ 0.0631 and $\mathrm{f}=0.0454$ for (A) and (B), respectively. Red indicates a loss of electron density in the transition, and blue indicates a gain in electron density for the transition. 


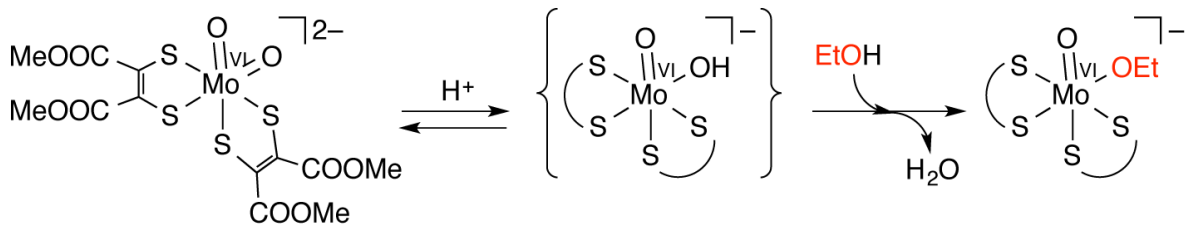

$\left[\mathrm{MoVl}^{\mathrm{V}} \mathrm{O}_{2} \mathrm{~L}_{2}\right]^{2-}$

$\left[\mathrm{Mo}^{\mathrm{V}} \mathrm{O}(\mathrm{OH}) \mathrm{L}_{2}\right]^{-}$

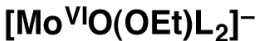

Scheme 1.

Postulated Scheme for the Formation of $\left[\mathrm{Mo}^{\mathrm{VI}} \mathrm{O}(\mathrm{OEt}) \mathrm{L}_{2}\right]^{-}$from $\mathrm{Mo}^{\mathrm{VI}} \mathrm{O}_{2} \mathrm{~L}_{2}$ and Ethanol in the Presence of Acid. 


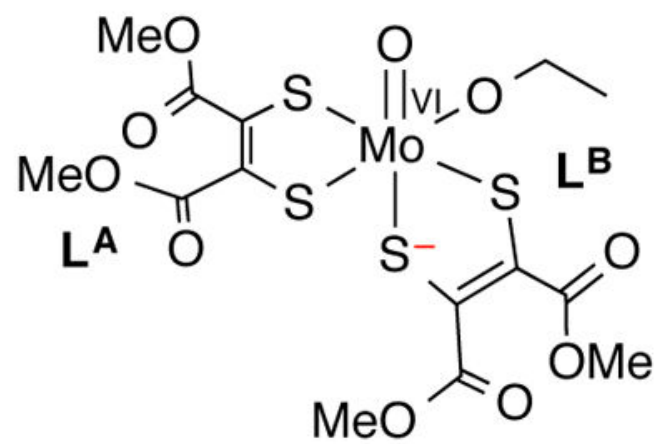

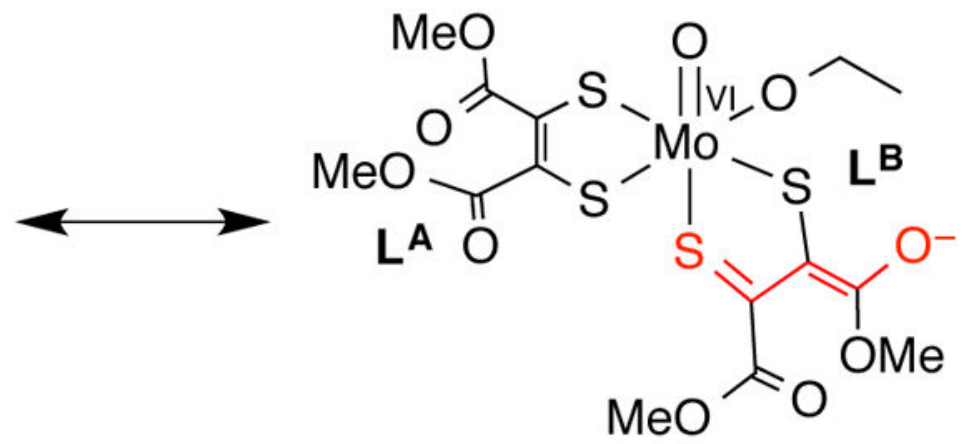

Scheme 2.

$\pi$-Conjugation Involved in Ligand $\mathrm{L}^{\mathrm{B}}$ Caused by trans Influence of Strong $\pi$-Donation of the Oxide Ligand. 


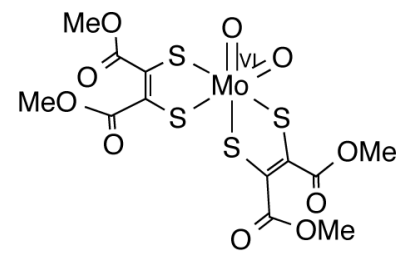

$\left[\mathrm{MoV}^{\mathrm{V}} \mathrm{O}_{2} \mathrm{~L}_{2}\right]^{2-}$

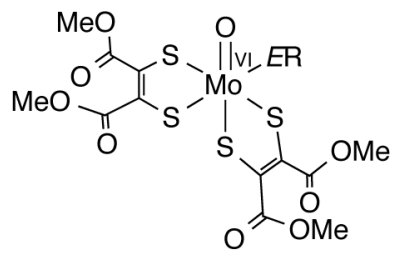

$\left.{ }^{[M o}{ }^{\mathrm{VI}} \mathrm{O}(E R) \mathrm{L}_{2}\right]^{-}$

$E=\mathrm{O}, \mathrm{S}$

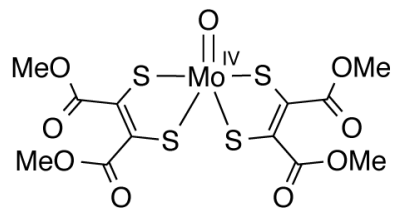

$\left[\mathrm{Mo}^{\mathrm{IV}} \mathrm{OL}_{2}\right]^{2-}$

Chart 1.

Structures of the $\mathrm{Mo}^{\mathrm{VI}}$ and $\mathrm{Mo}^{\mathrm{IV}}$ Model Complexes 


\section{Table 1}

Crystallographic Data for $\left(\mathrm{PPh}_{4}\right)\left[\mathrm{Mo}^{\mathrm{VI}} \mathrm{O}(\mathrm{OEt}) \mathrm{L}_{2}\right] \bullet$ acetone

\begin{tabular}{ll}
\hline formula & $\mathrm{C}_{41} \mathrm{H}_{43} \mathrm{MoO}_{11} \mathrm{PS}_{4}$ \\
Fw & 966.94 \\
size (mm) & $0.04 \times 0.03 \times 0.01$ \\
temperature (K) & 93 \\
crystal system & monoclinic \\
space group & $P 2_{1}(\# 4)$ \\
$Z$ & 2 \\
$a, \AA$ & $11.0598(7)$ \\
$b, \AA$ & $16.9292(11)$ \\
$c, \AA$ & $11.8567(8)$ \\
a, deg & 90 \\
$\beta$, deg & $100.879(8)$ \\
$\gamma$, deg & 90 \\
$V, \AA^{3}$ & $2180.1(3)$ \\
$\mu$, cm & \\
no. reflns $\left(\triangleright 2 \mathrm{~s} I_{o}\right)$ & 7074 \\
no. reflns (all data) & 12615 \\
no. variables & 558 \\
$\mathrm{GOF}$ & 0.930 \\
$R_{I} \%(\triangleright 2.0 \mathrm{~s} I)$ & 0.0558 \\
$w R_{2} \%$ (all data) & 0.1335 \\
\hline &
\end{tabular}

$R 1=\Sigma\left(\left|F_{\mathrm{o}}\right|-\mid \mathrm{Fc}\right) / \Sigma\left|F_{\mathrm{o}}\right| \cdot w R 2=\left\{\Sigma\left(\mathrm{w}\left(\mathrm{Fo}^{2}-\mathrm{Fc}^{2}\right)^{2}\right) / \Sigma w\left(F_{0}^{2}\right)^{2}\right\}^{1 / 2}$. 
Table 2

올

$\lambda_{\max }$ Values in a Visible Region of $\mathrm{Mo}^{\mathrm{VI}} \mathrm{O}(E \mathrm{R}) \mathrm{L}_{2}$ in $\mathrm{C}_{2} \mathrm{H}_{5} \mathrm{CN}$ at $-60{ }^{\circ} \mathrm{C}$

\begin{tabular}{l|l}
\hline$E \mathrm{R}$ & $\lambda \max \left(\varepsilon, \mathrm{M}^{-1} \mathrm{~cm}^{-1}\right)$ \\
\hline$O \mathrm{Et}$ & $539(2430), 742(2130)$ \\
\hline$O \mathrm{Pr}$ & $544(2780), 732(1610)$ \\
\hline$O \mathrm{CH}_{2} \mathrm{Ph}$ & $535(2860), 712(1840)$ \\
\hline$O \mathrm{Si}^{\mathrm{i}} \mathrm{Pr}_{3}{ }^{a}$ & $563(4300), 753(1280)$ \\
\hline${S \mathrm{C}_{6} \mathrm{H}_{13} b}^{b}$ & $639(4120), 774(1330)$ \\
\hline
\end{tabular}

${ }^{a}$ R. T.

${ }^{b}-80^{\circ} \mathrm{C}$. 
Table 3

Selected Bond Lengths $(\AA)$ and Angles $\left({ }^{\circ}\right)$ of $\left[\mathbf{M o}^{\mathbf{V I}} \mathbf{O}(\boldsymbol{O E t} / \mathbf{S E t}) \mathbf{L}_{2}\right]^{-}$

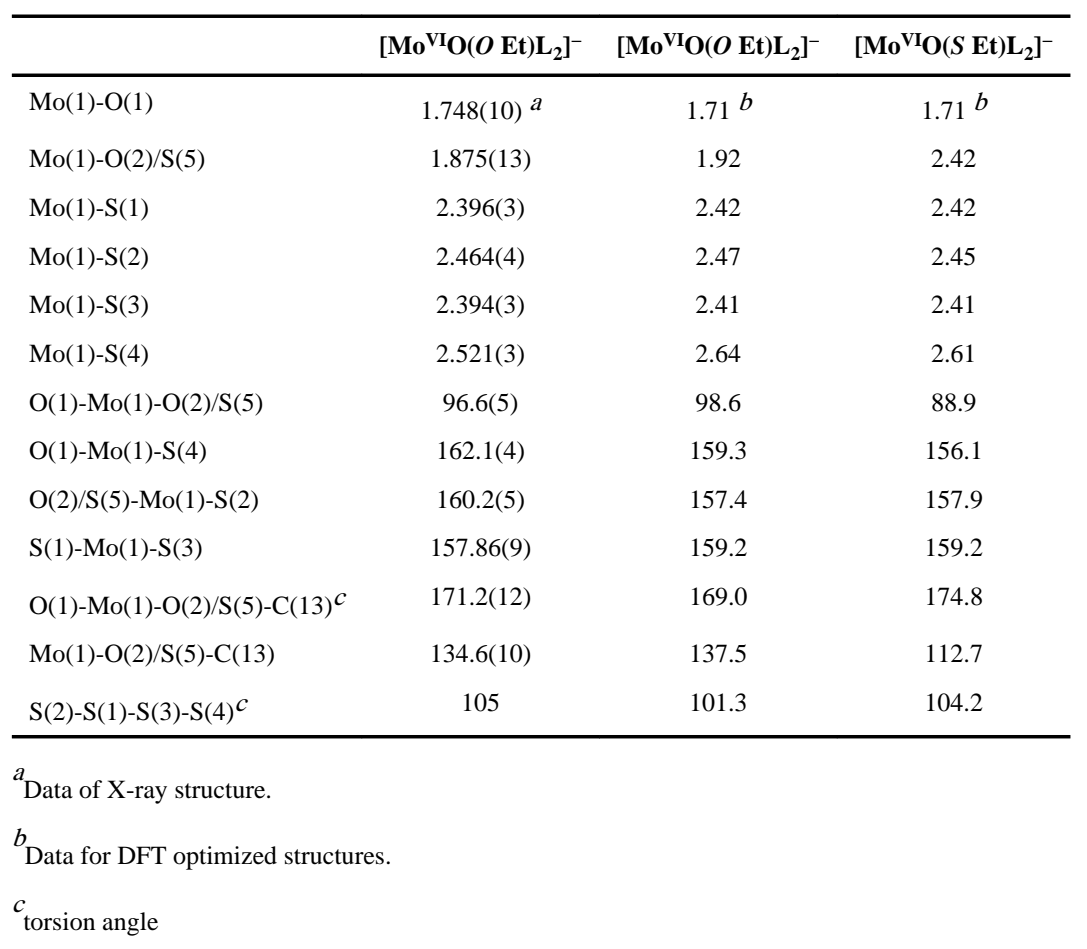




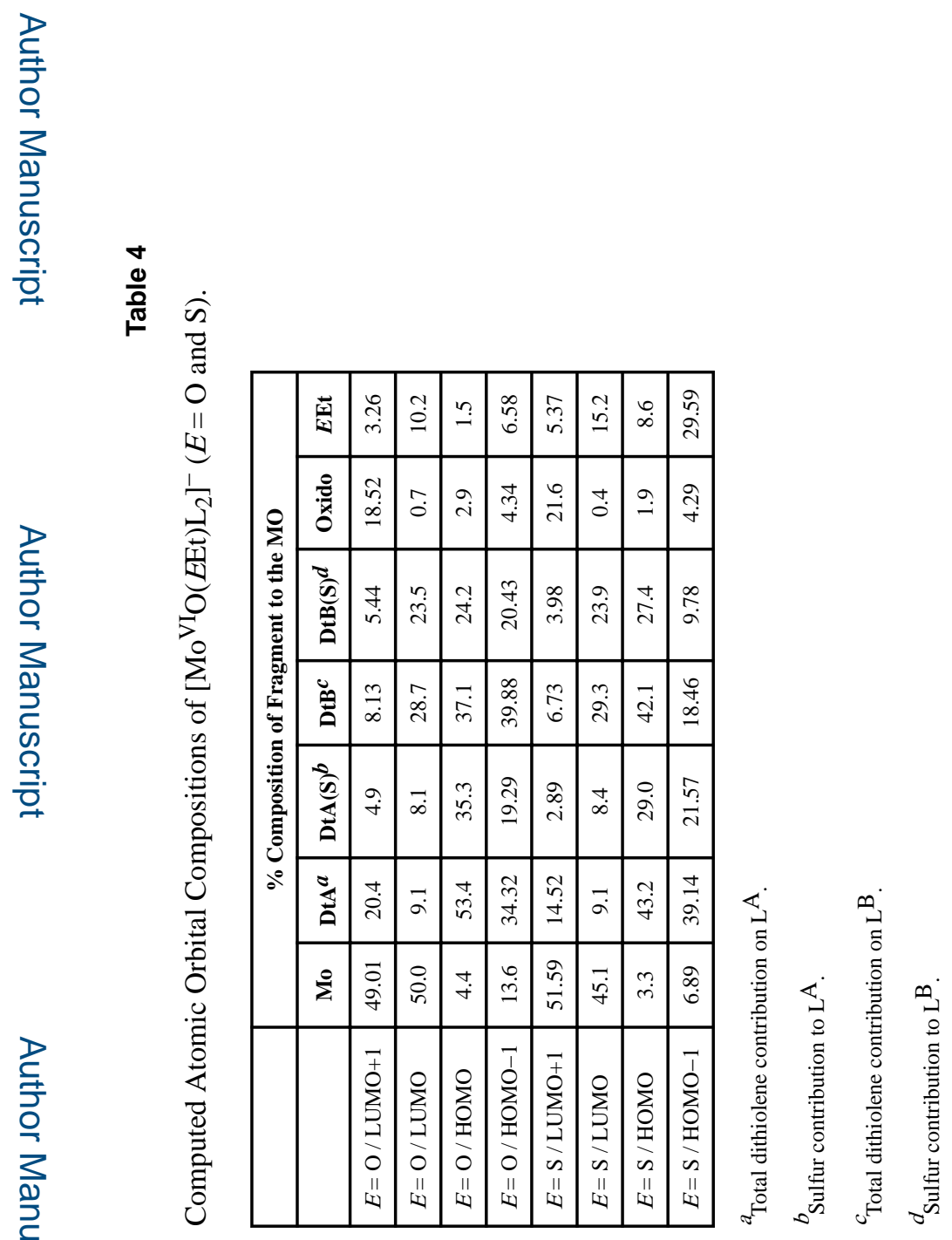

